Article

\title{
A Novel Approach to Isolation and Screening of Calcifying Bacteria for Biotechnological Applications
}

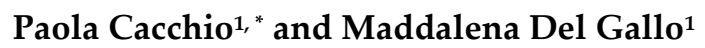 \\ ${ }^{1}$ Department of Life, Health \& Environmental Sciences, Microbiology Laboratory, University of L'Aquila, Coppito, \\ 67010 L'Aquila, Italy; paola.cacchio@univaq.it; mariamaddalena.delgallo@univaq.it \\ * Correspondence to: paola.cacchio@univaq.it
}

\begin{abstract}
Bacterial Calcium-carbonate Precipitation (BCP) has been studied for multiple applications such as remediation, consolidation and cementation. Isolation and screening of strong calcifying bacteria is the main task of $\mathrm{BCP}$-technique. In this paper we studied $\mathrm{CaCO}_{3}$ precipitation by different bacteria isolated from a rhizospheric soil in both solid and liquid media. It has been found, through culture-depending studies, that bacteria belonging to Actinobacteria, Gammaproteobacteria and Alphaproteobacteria are the dominant bacteria involved in $\mathrm{CaCO}_{3}$ precipitation in this environment. Pure and mixed cultures of selected strains were applied for sand biocementation experiments. Scanning Electron Microscopy (SEM) and Energy Dispersive X-ray Spectroscopy (EDS) analyses of the biotreated samples revealed the biological nature of the cementation and the effectiveness of the biodeposition treatment by mixed cultures. X-ray diffraction (XRD) analysis confirmed that all the calcifying strains selected for sand biocementation precipitated $\mathrm{CaCO}_{3}$, mostly in the form of calcite. In this study Biolog ${ }^{\circledR}$ Eco-plate is evaluated as a useful method for a more targeted choice of the sampling site with the purpose of obtaining interesting candidates for BCP applications. Furthermore, ImageJ software was investigated, for the first time to our knowledge, as a potential method to screen high $\mathrm{CaCO}_{3}$ producer strains.
\end{abstract}

Keywords: Bacterial Calcium-carbonate Precipitation (BCP); calcifying bacteria selection; calcifying mixed cultures; ImageJ software; Biolog EcoPlates; sand biocementation

\section{Introduction}

In natural environments, chemical $\mathrm{CaCO}_{3}$ precipitation is accompanied by microbial processes involving bacteria, particularly cyanobacteria, archaea, small algae and fungi [1]. Bacterial Calcium-carbonate Precipitation (BCP) is of major ecological and geological importance, and it has been widely studied in soils, caves, lakes, spring, and seawater, as well as in the laboratory [2-15]. Chemical $\mathrm{CaCO}_{3}$ precipitation is a rather straightforward process governed mainly by concentration of non-precipitated calcium, concentration of the total inorganic carbon, $\mathrm{pH}$, and availability of nucleation sites for $\mathrm{CaCO}_{3}$ crystal formation [16-18]. Bacteria can alter these factors, either separately or in combinations with one another, in a number of ways linked to cell surface structures and metabolic activities [16-36]. For example, in super-saturated solution, bacteria can become the nucleus of mineral precipitation due to $\mathrm{Ca}^{2+}$ adsorption to the capsule, cellular surface membrane, cell wall, or EPS (Exo-Poly-Saccharides) layer [21, 23, 24, 25, 26]. Alternatively, in under-saturated solution, bacteria can induce precipitation of $\mathrm{CaCO}_{3}$ through metabolic pathways associated with photosynthesis [17, $19,28,29,32-34]$, nitrogen and sulfur cycles $[17,31]$ and ion exchange $\left(\mathrm{Ca}^{2+} / \mathrm{H}^{+}\right)$[20]. These different metabolic processes increase $\mathrm{pH}$ and/or dissolved inorganic carbon concentration, favoring $\mathrm{CaCO}_{3}$ precipitation.

The various ecological implications of BCP in biotechnology have been described by Zhu and Dittrich [37]. BCP applications include: bioremediation of metal contaminated soil and ground water; restoration and preservation of calcareous sculptural artefacts, historical monuments and civil buildings; bioconcrete; different geotechnical-engineering applications such as soil/sand strength, sand impermeability, mitigation of liquefaction, soil erosion control, impermeabilization of polluted soils and other soil improvement projects; Microbial Enhanced Oil Recovery (EOR); $\mathrm{CO}_{2}$ sequestration; filler for rubber, plastic and ink [38-41].

There are two ways to apply BCP technology to sand/soil improvement. The first (biostimulation) consists in increasing BCP naturally occurring in the soil, through specific nutrient injection until it reaches the desired level. To date, because of its simplicity, the most commonly studied system of applied BCP is urea hydrolysis via the enzyme urease. The second (bioaugmentation) consists in the use of selected calcifying bacteria that, 
in primis, produce $\mathrm{CaCO}_{3}$ crystals at high amount and speed, in suitable environment. Until now, calcifying bacteria for the different biotechnological uses have been isolated mainly from soil, freshwater and seawater, different $\mathrm{CaCO}_{3}$ deposits such as stalactites and stalagmites in caves [42] and screened based mostly on traditional method (which requires a large amount of reagent and time) [41]. However, there are few studies on the rhizosphere bacteria ability to precipitate $\mathrm{CaCO}_{3}[27,42]$ despite to the facts that root exudates include amino acids (whose metabolization produces the $\mathrm{pH}$ conditions necessary for $\mathrm{BCP}$ ), as well as low-molecular weight organic acids whose mineralization by heterotrophic bacteria can lead to $\mathrm{CaCO}_{3}$ precipitation in a circumneutral environment rich in dissolved calcium [20, 27].

In this study, we enriched a consortium of bacteria isolated from rhizosphere soil based on their ability to precipitate $\mathrm{CaCO}_{3}$. Then, we isolated several individual members of this community, and analyze their metabolism and biomineralization to screen strong $\mathrm{CaCO}_{3}$ depositor strains. The best strains were further characterized based on their ability to cement sand.

The novelty of this study lies above all in the microbiological approach to biocementation. It is based on the study of the indigenous microbial community of a rhizospheric soil (like in biostimulation) and then on the use of calcifying bacterial strains or their consortia (like in bioaugmentation) isolated from it. This because we attempted to optimize the choice of the sampling site by Biolog EcoPlate assay (assessing the carbonatogenic potential of the microbial community dwelling the soil) to obtain effective calcifying strains to be used also in other sites, as well as for biotechnological applications other than biocementation.

Biolog EcoPlates are 96-well plates, containing in triplicate 31 different substrates plus a control [43]. The substrates in the wells can be subdivided into five groups: carbohydrates $(\mathrm{n}=10)$, carboxylic acids $(\mathrm{n}=9)$, amines and amides $(n=2)$, amino acids $(n=6)$, and polymers $(n=4)$. These compounds occur naturally in the soil and most of them are exudate by plant root in the rhizosphere [44]. In each well there is a redox indicator (a tetrazolium salt) that changes from colorless into purple in the presence of metabolic activity of the microbial community. The intensity of the coloring, which is optically measured at $590 \mathrm{~nm}$, is proportional to the substrate utilization.

As to methodological novelty, we proposed the use of ImageJ [45-46] as a low cost and rapid method to assess the in vitro mineralization aptitude of calcifying strains. A calcifying strain is of interest from a biotechnological point of view, mainly, when it produces a large amount of crystals that can be evaluated, for example, by recovering the crystals from agar and weighing them [22]. This operation is time consuming and not always leads to the expected result because crystals can remain embedded in the microbial biofilm. The ImageJ, already used in many scientific applications, allows screening in a shorter time.

\section{Materials and Methods}

\subsection{Soil Sampling, Biolog EcoPlate assay and physico-chemical analyses}

In this study, we used the Biolog EcoPlates to assess the carbonatogenic potential of the microbial communities dwelling the rhizosphere soil of Pinus strobus (Pinaceae), with the purpose of choosing a proper sampling site for an efficient screening of calcifying bacterial strains (since bacterial mineralization of organic acids and amino acids are important metabolic pathways involved in $\mathrm{BCP}$ ). As the probability to select strong calcifying bacteria should likely increases starting the screening program from a soil dwelled by metabolically active, versatile and highly diversified microbial community, we used the Biolog EcoPlate assay to obtain information also in this regard.

The rhizosphere soil was sampled from the garden of a residential area located near L'Aquila (CentralItaly) at a depth of $5 \mathrm{~cm}$, using sterile tools. The composite sample, placed into a sterile container, was carried to the laboratory at room temperature and immediately subjected to Biolog EcoPlate assay (BIOLOG Inc., Hayward, CA, USA) and microbiological analyses, performed in triplicate. $3 \mathrm{~g}$ of soil were added to $27 \mathrm{~mL}$ of sterile physiological solution $(0.9 \% \mathrm{NaCl})$ into a sterile flask, stirred for $30 \mathrm{~min}$ at room temperature and then centrifuged for $2 \mathrm{~min}$ at $2000 \mathrm{rpm}$. The supernatant was collected and placed into a sterile Petri dish, under sterile condition. A multichannel pipette was used to inoculate $150 \mu \mathrm{L}$ of the bacterial suspension into each well of the Biolog EcoPlate. The microplates were placed in a sterile plastic envelope, hermetically sealed, in order to limit the dehydration of the wells and incubated at $28^{\circ} \mathrm{C}$. The metabolic fingerprints were analyzed by measuring the absorbance at the Biolog Microstation, immediately following the inoculation procedure, considered as time zero, then every $24 \mathrm{hrs}$ until $216 \mathrm{hrs}$. 
Microbial activity in each EcoPlate, was expressed as Average Well Color Development (AWCD), which gives the index of the total metabolic potential of the community [47]. AWCD was determined as follows (Equation 1):

$$
\operatorname{AWCD}=\sum_{i=1}^{31} \frac{O D i}{31}
$$

To calculate the AWCD at each reading time, the optical densities from each well $\left(\mathrm{OD}_{\mathrm{i}}\right)$ were corrected subtracting the initial reading at time zero of the same well, as well as of the blank one (inoculated but without a carbon source). $\mathrm{OD}_{590}=0.25$ was assumed as a threshold value, below which a substrate was considered as unmetabolized [47].

The following metabolic-ecological indexes were calculated based on the ODs at $120 \mathrm{hrs}$, when the community reached the plateau: i) metabolic Richness index $(R)$ as the number of oxidized substrates, that indicates the metabolic versatility of the community [48]; ii) the Shannon-Weaver index $\left(H^{\prime}\right)$, that measures the metabolic diversity of the species present. It was calculated as follows (Equation 2):

$$
H^{\prime}=-\sum_{i=1}^{R} p i(\operatorname{lnpi})
$$

where $\mathrm{p}_{\mathrm{i}}$ (the proportional color development of the well over total color development of all wells in the plate) is calculated as the ratio of the corrected absorbance value of each well (ODi) to the sum of the absorbance value $\left(\Sigma \mathrm{OD}_{\mathrm{i}}\right)$ of all wells in the plate [45] and iii) the Evenness index $(E)$. This index, calculated as $H^{\prime} / \ln R$, measures the variation in color development among wells and indicates the uniformity in the microbial growth on the different substrates, which can be related to a similar abundance of the different species [4749].

For a better knowledge of the material, physico-chemical properties of the sampled soil including $\mathrm{pH}$, organic carbon content $(\%)$, total nitrogen $(\%)$ and assimilable phosphorous concentrations $(\mathrm{mg} / \mathrm{Kg})$, Cation Exchange Capacity - CEC (meq) and exchangeable $\mathrm{Ca}^{2+}, \mathrm{Mg}^{2+}, \mathrm{K}^{+}, \mathrm{Na}^{+}(\mathrm{mg} / \mathrm{Kg})$, total and active calcium carbonate content (\%), Electric Conductivity - EC (mS), texture, sand, silt and clay fractions (\%) were determined according with the official methods [9].

As shown in Table 1, the sampled soil was a sandy-loam soil containing an average amount of total carbonates and a very high amount of $\mathrm{Ca}^{2+}$. Total $\mathrm{pH}$ was weak alkaline. The content of total $\mathrm{N}$ and available $\mathrm{P}$ were low and very low, respectively. 
Table 1. Physico-chemical properties of the soil sampled for the isolation of calcifying bacteria.

\begin{tabular}{|c|c|c|c|c|c|c|c|c|c|c|c|c|c|c|c|c|c|c|c|c|c|c|c|c|c|c|}
\hline Skel. & $\begin{array}{l}\text { Sand } \\
(\%)\end{array}$ & $\begin{array}{l}\text { Silt } \\
(\%)\end{array}$ & $\begin{array}{c}\text { Clay } \\
(\%)\end{array}$ & Text. & $\begin{array}{l}\text { O.S. } \\
(\%)\end{array}$ & $\mathrm{pH}$ & $\begin{array}{l}\text { E.C. } \\
\text { (mS) }\end{array}$ & $\begin{array}{l}\text { Tot. } \\
\mathrm{CaCO}_{3} \\
(\%)\end{array}$ & $\begin{array}{l}\text { Act. } \\
\mathrm{CaCO}_{3} \\
(\%)\end{array}$ & $\begin{array}{l}\mathrm{N} \\
(\%)\end{array}$ & $\begin{array}{l}\mathrm{Ca} \\
\text { (pp } \\
\mathrm{m})\end{array}$ & $\begin{array}{l}\mathrm{Mg} \\
\text { (pp } \\
\mathrm{m})\end{array}$ & $\begin{array}{l}\mathrm{K} \\
\text { (pp } \\
\mathrm{m})\end{array}$ & $\begin{array}{l}\mathrm{Na} \\
\text { (pp } \\
\mathrm{m})\end{array}$ & $\begin{array}{c}\mathbf{P} \\
\text { (ppm } \\
\text { ) }\end{array}$ & $\begin{array}{l}\mathrm{Fe} \\
(\mathrm{pp} \\
\mathrm{m})\end{array}$ & $\begin{array}{l}\text { Mn } \\
\text { (pp } \\
\text { m) }\end{array}$ & $\begin{array}{l}\mathrm{Cu} \\
\text { (pp } \\
\mathrm{m})\end{array}$ & $\begin{array}{l}\text { Zn } \\
\text { (pp } \\
\text { m) }\end{array}$ & $\begin{array}{l}\text { C.E.C. } \\
\text { (meq) }\end{array}$ & $\begin{array}{c}\mathrm{Ca} \\
\text { (meq } \\
\text { ) }\end{array}$ & $\begin{array}{l}\mathrm{Mg} \\
\text { (me } \\
\text { q) }\end{array}$ & $\begin{array}{l}\mathrm{K} \\
\text { (me } \\
\mathrm{q})\end{array}$ & $\begin{array}{c}\mathrm{Na} \\
\text { (meq } \\
\text { ) }\end{array}$ & $\begin{array}{l}\text { B. S. } \\
\text { (\%) }\end{array}$ & $\begin{array}{c}\mathrm{Mg} / \\
\mathrm{K}\end{array}$ \\
\hline Con. & 48 & 15 & 37 & C.S. & 1.06 & 7.6 & 0.403 & 16.4 & 3.0 & 0.07 & 4100 & 244 & 203 & 66 & 6 & 9.6 & 13.0 & 1.9 & 1.2 & 23.35 & 20.50 & 2.04 & 0.52 & 0.29 & 100 & 3.9 \\
\hline
\end{tabular}

carbonate content; $\mathrm{Act} . \mathrm{CaCO}_{3}=$ active calcium carbonate content; C.E.C. = Cation Exchange Capacity; B.S. = Basic Saturation. Sand, silt, clay, total and active calcium 


\subsection{Isolation of $\mathrm{CaCO}_{3}$ producing bacteria}

An amount of sample corresponding to $10 \mathrm{~g}$ of dried soil was resuspended in $90 \mathrm{~mL}$ sterile physiological solution and stirred for $50 \mathrm{~min}$ to detach the bacteria, whose external surface is negatively charged, from soil cations. Triplicate B4 agar plates [4] (2.5 g calcium acetate, $4.0 \mathrm{~g}$ yeast extract, $10.0 \mathrm{~g}$ glucose and $18.0 \mathrm{~g}$ Biolife agar per liter of distilled water, the final $\mathrm{pH}$ was adjusted to 8.0 with $\mathrm{NaOH}$ ) were inoculated with soil dilutions ranging from $10^{-2}-10^{-6}$ and incubated aerobically at $28^{\circ} \mathrm{C}$ for 24 or $48 \mathrm{hrs}$ (depending on the growth rate of the bacteria). B4 is an enrichment medium for calcifying bacteria; the acetate ion is an energy source, while the $\mathrm{Ca}^{2+}$ cation is used by the calcifying bacteria to precipitate calcium carbonate. The presence of glucose speeds the process. After its first description in 1973 [4], B4 medium was utilized by several Authors [50-54] to stimulate growth of calcifying bacterial species. The rationale is that calcifying heterotrophic bacteria belong to various groups with different nutritional and physiological properties so that the presence of nutrients widespread in the environment, like glucose and factors present in yeast extract, is expected to enlarge the platform of enriched strains. Colonies were assessed every 24/48 hrs with optical microscopy (Leitz-Biomed) and selected as positive based on visual crystal formation within 25 days. Positive isolates were purified by repeated streaking on B4 agar plates and preliminarily characterized.

A serial dilution of the soil sample was also plated in triplicate on Nutrient Agar (Difco) for Colony Forming Unit (CFU) counting.

Calcifying bacteria were preserved by various methods. For short-term preservation, strains were incubated at $28^{\circ} \mathrm{C}$ for $2-5$ days and then kept at $4^{\circ} \mathrm{C}$ on slants of B4. For long-term maintenance pure cultures were kept in glycerol at $-80^{\circ} \mathrm{C}$.

\subsection{Preliminary characterization and Biolog identification}

Morphological characterization of the bacterial colony was performed on the basis of pigmentation, form, elevation, margin, opacity, and surface [55]. Optical microscope (Leitz-Biomed, 40X and 100X) was used to establish the shape of the heat-fixed bacterial cells after Gram staining by the Color Gram 2 Kit (bioMérieux, Marcy-l'Etoile/France), following the kit instructions. Physiological characterization was performed on the basis of the relation to temperature (bacterial isolates were incubated on B4 agar at 4,20 and $28^{\circ} \mathrm{C}$, significant temperatures for in situ biocementation experiments) and oxygen presence (since anaerobic conditions are abundant in the soil, particularly when the rain saturates the soil and gas exchange slows down almost completely) by incubating bacterial strains on B4 agar in an anaerobic chamber (Oxoid, Hampshire, UK). The occurrence of a catalase reaction was demonstrated by the formation of bubbles after mixing a suspension of one-day bacterial cultures with a drop of $3 \%(\mathrm{v} / \mathrm{v})$ hydrogen peroxide water-solution on slide. Urease activity of calcifying strains was detected on Christensen agar medium containing $2 \%$ urea and phenol red as $\mathrm{pH}$ indicator [56, 57]. We cooled the sterilized medium $\left(115^{\circ} \mathrm{C}\right.$ for $\left.20 \mathrm{~min}\right)$ to $40-50^{\circ} \mathrm{C}$, before adding the urea supplement. Inoculated agar slants were incubated at $28^{\circ} \mathrm{C}$ for $24 / 48 \mathrm{hrs}$ and observed for color change after 6,24 , and $48 \mathrm{hrs}$ of incubation. Microorganisms with urease activity hydrolyze urea with the ammonium ions production causing a change of color of the agar medium to fuchsia (alkaline $\mathrm{pH})$.

Biolog GN2 and GP2 plates (Biolog, Inc., Hayward, Calif.) were used for the identification of Gramnegative and Gram-positive bacteria, respectively. One or two days (depending on the growth rate of the bacterium) before the inoculation on Biolog GN2 and GP2 plates, bacterial strains were streaked on Biolog Universal Growth Agar (BUG) and incubated at $28^{\circ} \mathrm{C}$. Inoculation and reading of micro-plates were carried out according to the instructions of manufacturer using a Biolog Microstation with OmniLog. Biolog method is based on oxidation tests of 93 substrates in a 96 well-microtiter plate. Each well contains a redox dye, tetrazolium violet, that allows colorimetric determination of the increased respiration that occurs when microbial cells are oxiding a C-substrate. Reactions were compared to the GP or GN database based on the similarity index which must be at least 0.75 to be considered an acceptable species identification after 4 hrs of incubation and at least 0.50 after $16-24$ hrs of incubation.

\subsection{Calcification and $\mathrm{CaCO}_{3}$ solubilization activities}

Pure bacterial cultures on B4 agar plates were observed every 24/48 hrs under a light microscope (Leitz-Biomed, 10X) for up to 25 days after inoculation, to follow crystal production by the bacterial strains at 
different temperatures, under aerobic condition. Three temperatures 4,20 and $28^{\circ} \mathrm{C}$ were selected to test the induction of carbonate precipitation by the bacterial isolates, as representative of natural conditions. The bacterial aptitude for calcification was evaluated on the basis of: i) $\mathrm{CaCO}_{3}$ crystal amount on $\mathrm{B} 4$ agar, ii) size of the $\mathrm{CaCO}_{3}$ bioliths, iii) presence of $\mathrm{CaCO}_{3}$ aggregates, iv) time to initiate the precipitation activity. Position of crystals on B4 agar (on the colony, in proximity, or far away in the medium) was also checked.

Calcifying bacterial strains were inoculated also into $100 \mathrm{~mL}$ of sterile B4 liquid medium, to assess their capability to precipitate in liquid conditions. Inoculated flasks were incubated under static conditions at $28^{\circ} \mathrm{C}$ for two months. The presence of crystals was macroscopically assessed both at the bottom of the flasks and on the wall.

As microbial mediated reactions can generate considerable amounts of $\mathrm{H}^{+}$ions that can dissolve $\mathrm{CaCO}_{3}$ deposits, we tested the ability of the selected calcifying strains to dissolve $\mathrm{CaCO}_{3}$ after 7,15 and 30 days of incubation at $28^{\circ} \mathrm{C}$. Calcifying isolates were grown on Deveze-Bruni medium (1.0 g peptone, $1.0 \mathrm{~g}$ yeast

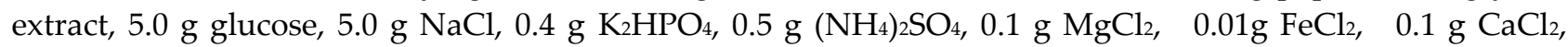
$\mathrm{pH}=6.8)$ supplemented with $0.14 \%$ or $2.5 \%(\mathrm{w} / \mathrm{v}) \mathrm{CaCO}_{3}$ [58]. Solubilization activity was shown as clear halo that surrounded each colony in response to decreased $\mathrm{pH}$ [59].

\subsection{Image analysis}

In the present research, the ImageJ software was evaluated as a rapid screening method to estimate the extent of $\mathrm{CaCO}_{3}$ production on $\mathrm{B} 4$ agar plates by each calcifying bacterial strain, after 30 days of growth at $28^{\circ} \mathrm{C}$. ImageJ analysis was performed from digital images of 5 different areas (total area $=125 \times 5 \mathrm{~mm}^{2}$ ) of the inoculated B4 agar plates (plate area $=6359 \mathrm{~mm}^{2}$ ) observed upside down at optical microscope (Leitz-Biomed, 10X) (Figure 1). These areas were randomly chosen and acquired through an iPhone, used as the camera, directly from the eyepiece of the microscope. By ImageJ analysis we calculated: the total area occupied by the crystals on each optical image and the mean (with its standard deviation) on each set of the 5 images, to obtain the percent average surface covered by $\mathrm{CaCO}_{3}$ crystals (referred as $\mathrm{BCP}$ extent) deposited in vitro by each calcifying strain. In this preliminary study, the scale bar was determined by a micrometric slide.

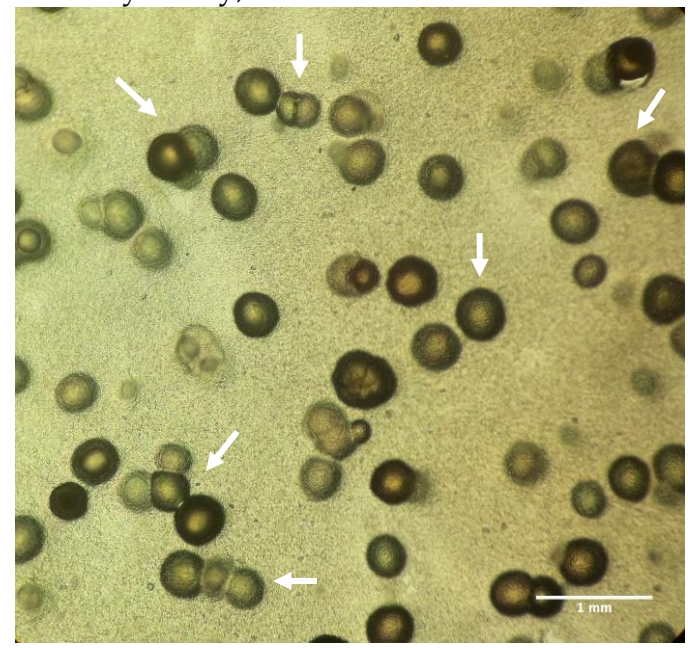

Figure 1. A digital image acquired through an iPhone (used as the camera) of an inoculated B4 agar plate, observed upside down at optical microscope (Leitz-Biomed, 10x). Note globular $\mathrm{CaCO}_{3}$ crystals of different dimensions and their aggregates precipitated by the strain P1 (arrows), after 30 days of growth at $28^{\circ} \mathrm{C}$.

\subsection{Sand biocementation test}

Experiments of consolidation by BCP were carried out using sand samples from the Adriatic-sea coast (Central Italy) and bacterial calcifying cultures selected during this study. Table 2 shows some of the physical and chemical characteristics of the sand used in this study. 
Table 2. Physico-chemical properties of the sea sand utilized for biocementation experiments.

\begin{tabular}{|c|c|c|c|c|c|c|c|c|c|c|c|c|c|c|c|c|c|c|c|c|c|c|c|c|c|c|}
\hline Skel. & $\begin{array}{c}\text { San } \\
\text { d } \\
(\%)\end{array}$ & $\begin{array}{c}\text { Sil } \\
\mathbf{t} \\
(\% \\
)\end{array}$ & $\begin{array}{c}\text { Cla } \\
\text { y } \\
(\%)\end{array}$ & $\begin{array}{l}\text { Te } \\
\text { xt. }\end{array}$ & $\begin{array}{c}\text { O.M. } \\
(\%)\end{array}$ & $\mathrm{pH}$ & $\begin{array}{c}\text { E.C. } \\
\text { (mS } \\
)\end{array}$ & $\begin{array}{l}\text { Tot. } \\
\mathrm{CaCO}_{3} \\
(\%)\end{array}$ & $\begin{array}{l}\text { Act. } \\
\mathrm{CaCO}_{3} \\
(\%)\end{array}$ & $\begin{array}{c}N \\
(\%)\end{array}$ & $\begin{array}{c}\text { Ca } \\
(\mathrm{ppm} \\
\quad)\end{array}$ & $\begin{array}{l}\mathrm{Mg} \\
\text { (pp } \\
\mathrm{m})\end{array}$ & $\begin{array}{l}\text { K } \\
\text { (pp } \\
\text { m) }\end{array}$ & $\begin{array}{l}\mathrm{Na} \\
\text { (pp } \\
\mathrm{m})\end{array}$ & $\begin{array}{c}P \\
\text { (pp } \\
\text { m) }\end{array}$ & $\begin{array}{l}\mathrm{Fe} \\
\text { (pp } \\
\mathrm{m})\end{array}$ & $\begin{array}{l}\text { Mn } \\
\text { (pp } \\
\text { m) }\end{array}$ & $\begin{array}{l}\mathrm{Cu} \\
\text { (pp } \\
\mathrm{m})\end{array}$ & $\begin{array}{c}\text { Zn } \\
\text { (ppm } \\
\text { ) }\end{array}$ & $\begin{array}{l}\text { C.E.C. } \\
\text { (meq) }\end{array}$ & $\begin{array}{c}\mathrm{Ca} \\
\text { (me } \\
\mathrm{q})\end{array}$ & $\begin{array}{c}\mathrm{Mg} \\
\text { (me } \\
\text { q) }\end{array}$ & $\begin{array}{c}\mathrm{K} \\
\text { (me } \\
\mathrm{q})\end{array}$ & $\begin{array}{c}\mathrm{Na} \\
\text { (me } \\
\mathrm{q})\end{array}$ & $\begin{array}{c}\text { B. S. } \\
(\%)\end{array}$ & $\begin{array}{c}\mathrm{Mg} / \\
\mathrm{K}\end{array}$ \\
\hline TRA. & 94 & 2 & 4 & S. & 0.04 & 7.9 & 0.57 & 33.9 & 0.9 & 0.009 & 2940 & 77 & 54 & 119 & 6 & 3.6 & 4.6 & 0.4 & 0.8 & 16.01 & 14.7 & 0.65 & 0.14 & 0.52 & 100 & 4.6 \\
\hline
\end{tabular}

Skel. = Skeleton; TRA. = trace; Text.= texture; S. =sandy; O.M.= organic matter; E.C.= Electric Conductivity; Tot. CaCOz= total calcium carbonate content; Act. $\mathrm{CaCO}_{3}=$ active calcium carbonate content; C.E.C. $=$ Cation Exchange Capacity; B.S. = Basic Saturation. Sand, silt, clay, total and active calcium carbonate values are wt \%.

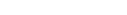


The sand was characterized by a weak alkaline $\mathrm{pH}$, a medium content of total carbonates and a high level of exchangeable $\mathrm{Ca}^{2+}$. The content of organic matter as well as of total $\mathrm{N}$ and assimilable $\mathrm{P}$ were very low.

The following biocementation experiments were set up: i) $7 \mathrm{~g}$ of sand, on Petri dish, for 3 weeks; ii) $300 \mathrm{~g}$ of sand, in Magenta vessel, for 2 months; iii) $300 \mathrm{~g}$ of sand, in Magenta vessel, for 2 months in the presence of equimolar $(1 \mathrm{M})$ urea and calcium chloride, as calcification inducing-agents. Control specimens were sand samples treated with not inoculated B4 medium.

For sand biocementation on Petri dish, strain selection was based on: i) calcification extent (\% area covered by $\mathrm{CaCO}_{3}$ crystals precipitated on $\mathrm{B} 4$ agar plates) established by ImageJ software. This parameter depends on amount and size of the precipitated $\mathrm{CaCO}_{3}$ crystals, presence of $\mathrm{CaCO}_{3}$ aggregates, days to initiate bio-precipitation, $\mathrm{CaCO}_{3}$ solubilization activity; ii) calcification parameters not included in the calcification extent, such as biodeposition in liquid medium and capability to precipitate $\mathrm{CaCO}_{3}$ at different temperatures; iii) cell morphology; iv) relation with oxygen; v) Gram-staining. $7 \mathrm{~g}$ of washed sand, sterilized at $120^{\circ} \mathrm{C}$ for 20 minutes and dried in a oven, were homogenously distributed on a $90 \mathrm{~mm}$ Petri dish and then inoculated with $25 \mathrm{~mL}$ of a calcifying cell suspension $\left(10^{7} \mathrm{CFU} / \mathrm{mL}\right)$, grown on B4 medium. Biopretreated samples were incubated at $28^{\circ} \mathrm{C}$ statically, to allow the bacteria to cement the sand.

To test BCP in depth, $300 \mathrm{~g}$ of sand were placed in a Magenta vessel and inoculated with $150 \mathrm{~mL}$ of a calcifying cell suspension $\left(10^{6} \mathrm{CFU} / \mathrm{mL}\right)$, grown on B4 medium, in the presence or not of the inducing agents (equimolar urea and calcium chloride). For sand biocementation in Magenta vessel, strain selection was based on: i) calcification extent (established by ImageJ software), ii) ability to precipitate $\mathrm{CaCO}_{3}$ crystals in $\mathrm{B} 4$ liquid medium, iii) ability to hydrolyze urea and iv) growth in anaerobiosis.

\subsection{SEM, XRD and EDS analyses}

Scanning Electron Microscopy (SEM) was used to study crystal morphology and their relationship with microbial cells. Samples were prepared as follows: samples on agarized media were dried at $37^{\circ} \mathrm{C}$ for 40 days; agar medium was cut into flat blocks, gold-sputtered, and observed with a Philips SEM XL30CP. For crystallite-poor samples, the agar was dissolved and crystals were collected and purified according to the method of Rivadeneyra [22].

XRD was used to identify $\mathrm{CaCO}_{3}$ mineral phases of the bioprecipitated crystals. XRD analyses were done by a two-circle $\theta / 2 \theta$ diffractometer with a $\mathrm{Cu}$ radiation source (Bruker D5000). The supply voltage of the $\mathrm{X}$ ray tube was set at $40 \mathrm{kV}, 40 \mathrm{~mA}$. The $2 \theta$ scan range was between $20^{\circ}$ and $60^{\circ}$; each scan was done in steps of 0.02. A counting time between 30 and 40 seconds per step was selected, depending on the sample density. The crystalline phases were identified using the ICDD database (JCPDS). XRD samples were prepared as follows: cultured solid media were dried at $32^{\circ} \mathrm{C}$, agar medium was cut into $10 \times 30 \mathrm{~mm}$ flat blocks, $0.5 \mathrm{~mm}$ high, and those richest in crystallites were fixed by adhesive tape on a glass slide for $\mathrm{X}$-ray measurements.

SEM and EDS were used to detect, after 20 days-treatment, the nature of sand cementation by the calcifying cultures. For EDS, samples were dried, uniformly spread directly on adherent tabs and analyzed without gold film. SEM-EDS analysis was performed by a SEM-Philips XL30CP and a EDX-INCA ENERGY 250 .

XRD and EDS were also used to study the untreated sea sand.

\section{Results and Discussion}

\subsection{Biolog EcoPlates assay}

Since BCP is influenced by the metabolic activity of the bacteria, we investigated through the Biolog EcoPlates the metabolic activity of the bacterial communities dwelling a rhizospheric soil, with the purpose of choosing a good sampling site for an efficient calcifying bacteria screening. In the literature there is a lot of information about the possibilities of using the Biolog EcoPlates to analyze functional microbial diversity in the presence of different plant and cultivation type, and to study the metabolic activity of microorganisms in soils contaminated with pesticides and heavy metals.

To our knowledge, Andrei and co-workers [60] were the first to use Biolog EcoPlates to investigate the carbonatogenic potential of bacterial communities (dwelling a limestone statue in Romania), based on their ability to metabolize amino acids since this metabolization promotes the $\mathrm{pH}$ conditions necessary for the 
biomineralization process (by ammonia released in the process of oxidative deamination). Overall, Andrei and co-workers study, highlights the need to evaluate the carbonatogenic potential of the bacterial communities present on a stone artwork prior to designing an efficient conservation treatment based on resident calcifying bacteria. On the same line, we used the Biolog EcoPlate assay to assess the carbonatogenic potential of the bacterial community dwelling a rhizospheric soil at the aim of starting an efficient screening program of calcifying bacteria.

Unlike Andrei and co-workers, in this study we have correlated the carbonatogenic potential of the bacterial communities to the metabolic use not only of the amino acids but also of the organic acids present in the Biolog EcoPlate. This because both these carbon compounds occur naturally in the rhizospheric soil environment, as plant root exudates, as well as because low-molecular weight organic acids mineralization by heterotrophic bacteria is another microbial process that (increasing both $\mathrm{pH}$ and concentration of dissolved inorganic carbon) can lead to calcium carbonate precipitation in a circumneutral environment rich in dissolved calcium. As $\mathrm{CaCO}_{3}$ precipitation always appears to be a response of the heterotrophic bacterial communities to an enrichment of the environment in organic matter in aerobiosis, anaerobiosis and microaerophilia, this mineralization process has been commonly used in microbial carbonate precipitation experiments [17, 20]. Moreover, since the probability of obtaining efficient $\mathrm{CaCO}_{3}$ producer strains increases likely in the presence of bacterial communities highly biodiversified with a high catabolic versatility, we used the Biolog EcoPlate assay also to obtain information about these metabolic and ecological aspects. Based on these considerations, all the information of the studied rhizospheric soil obtained through Biolog EcoPlate system revealed its usefulness to start a successful screening of calcifying bacteria. In fact, we found that at the end of the incubation period, the soil microbial community used 29 out of 31 different substrates (metabolic Richness index $R=29$ ) present in the Biolog EcoPlate, including all the amino acids and almost all the organic acids (apart from 2-hydroxybenzoic acid and $\alpha$-ketobutyric acid). This means that the microbial community under study had a high functional diversity and catabolic versatility as well as a good mineralization potential of $\mathrm{CaCO}_{3}$ (the utilization of all the six amino acids, as well as of almost all the carboxylic acids indicates the presence in the soil of favorable conditions for the growth of microorganisms carrying the enzymes taking part in metabolic pathways of BCP). The general catabolic activity of the soil community to utilize the Csubstrates, turned out to be not only wide (as shown by the metabolic Richness index, R) but also high as shown by the dynamic of the AWCD during the incubation time of the EcoPlates, at $28^{\circ} \mathrm{C}$ (Figure 2).

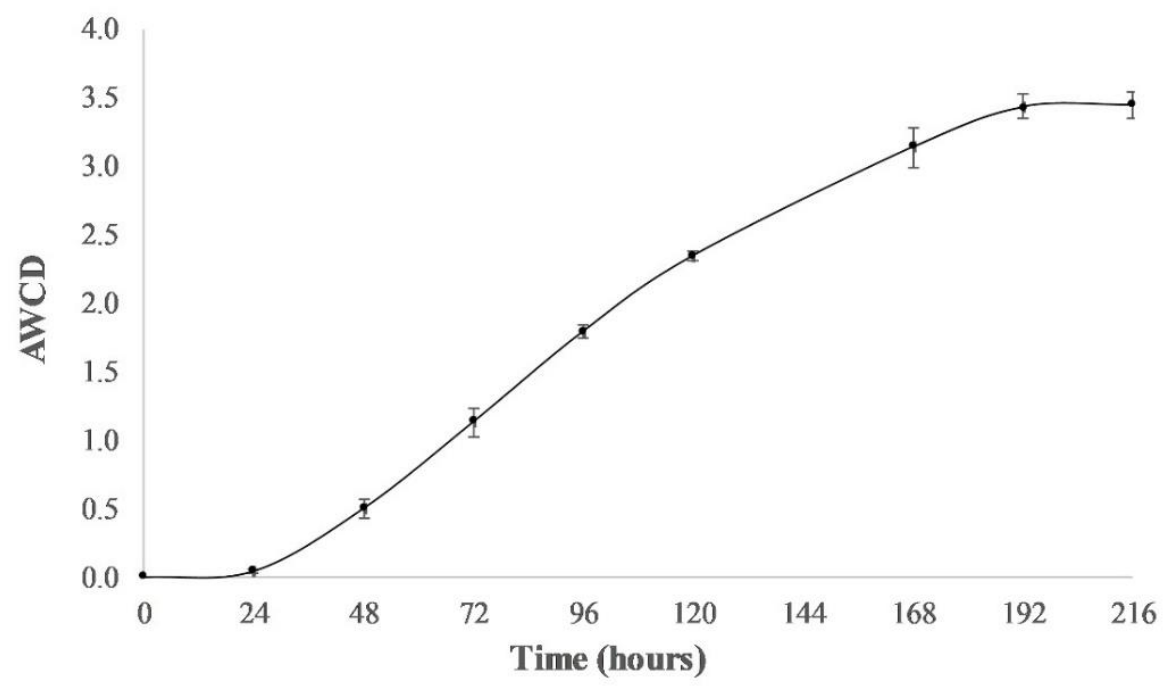

Figure 2. Dynamic of the Average Well Color Development (AWCD) of the rhyzospheric-soil sample during the incubation time ( 9 days), at $28^{\circ} \mathrm{C}$ (AWCD points are means of three replicates). Data were corrected subtracting the initial readings (at $590 \mathrm{~nm}$ ) at time zero, as well as the reading of the control well (inoculated but without a C-substrate). The curve shows how the microbial community had a long lag-time in the development of formazan products within the Biolog-plate wells. Development was consistent and linear over the entire incubation period (9-days). The number of positive wells increased slowly for the first 24 hours and then increased up to 192 hours of incubation, when stationary phase began. 
Figure 3 showed that microbial functional diversity changed over time, and that the microbial community initially prefer C-substrates from the carboxylic and amino acid groups (namely D-Galacturonic acid and LAsparagine), in addition to Glucose-1-phosphate. During the exponential phase, an increasing number of substrates (belonging to all five groups) was utilized (Figure 3). However, the diversification over time of the microbial substrate use from the different groups (polymers, carbohydrates, carboxylic acids, amino acids and amines) is beyond the aim of this research and will not be further discussed.

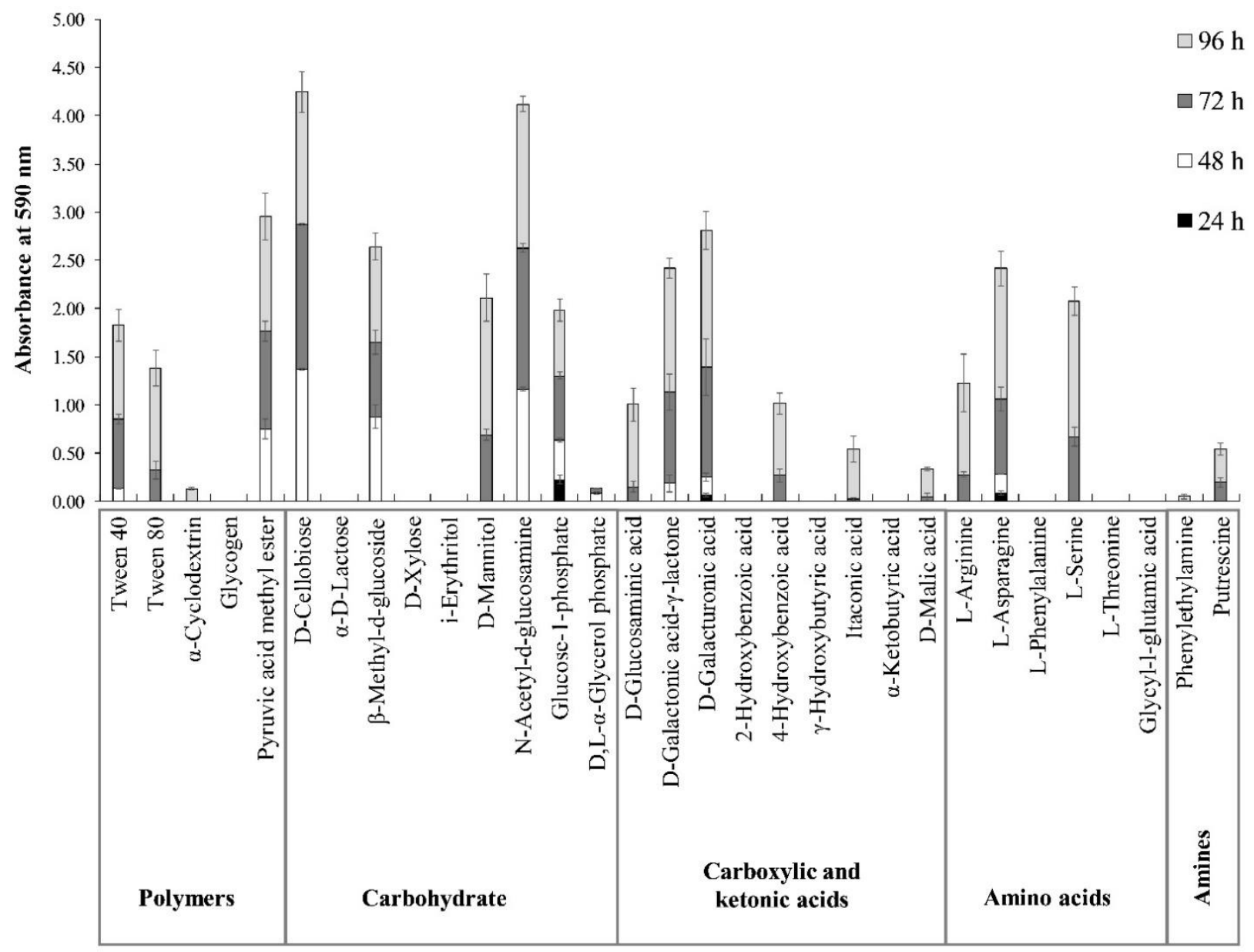

Figure 3. - Stacked columns showed the diversification over time of the substrate use from the different groups (polymers, carbohydrates, carboxylic and ketonic acids, amino acids and amines) by the soil microbial community. In the figure are reported absorbances (recorded at $590 \mathrm{~nm}$ ) for each substrate from 0 to 48 hours (A), from 72 to 96 hours (B), and from 96 to 216 (C). The chart shows how the substrate use in the first 24 hours (during the lag-phase, Figure 2), is limited to Glucose-1-phosphate, L-Asparagine and D-Galacturonic acid. During the exponential phase, an increasing number of substrates (belonging to all five groups) was used by the microbial community.

The substrate uniformity index $(E)$ value was 0.95 , highlighting a high uniformity in the activity of the different substrates (that can be related to a similar abundance of the different species), indicating from our specific point of view, a greater chance of isolating bacteria capable to perform ammonification (of amino acids) and low-molecular weight organic acid mineralization. Finally, the Shannon-Weaver index $\left(H^{\prime}\right)$ was equal to 3.20, highlighting a high diversity of the species present related to the high diversity of nutrients available for growth in the root zones, including amino acids and organic acids [61].

\subsection{Isolation and preliminary characterization of heterotrophic calcifying bacterial strains}

By using traditional cultivation techniques, a discrete cultivable heterotrophic bacterial community was isolated from the sampled rhizospheric soil $\left(4.5 \times 10^{5} \mathrm{CFU} / \mathrm{g}\right.$ d.w.). The cultivable heterotrophic bacterial density was lower than expected (106-10 ${ }^{10} \mathrm{CFU} / \mathrm{g}$ d.w.), possibly because sampling was done in winter. In a 
previous work [9] we also found that the cultivable microbial biomass is significantly related to the silt fraction, negatively related to the clay fraction and negatively related to the $\mathrm{Ca}^{2+}$ content (Table 1). As expected, based on the weak alkaline $\mathrm{pH}$ value (Table 1), bacteria represented $78 \%$ of the cultivable microbial population. Fungi were the remaining component. Fourteen morphologically different heterotrophic bacteria (named from P1 to P14, where P stands for pure) were isolated from this microbial community and purified by streaking on B4 agar. Table 3 shows characterization results of the bacterial calcifying isolates.

Table 3. Morphological, physiological and biochemical traits of the heterotrophic calcifying bacteria isolated from a rhizospheric soil near L'Aquila (Central Italy).

\begin{tabular}{|c|c|c|c|c|c|c|c|}
\hline Strain & Cell & Gram & $4^{\circ} \mathrm{C}$ & $20^{\circ} \mathrm{C}$ & $28^{\circ} \mathrm{C}$ & $\begin{array}{l}\text { Anaerobic } \\
\text { growth }\end{array}$ & Urease \\
\hline P1 & Short rod & + & - & + & + & - & ++ \\
\hline $\mathbf{P 2}$ & Short rod & - & - & + & + & - & ++ \\
\hline P3 & Short/irregular rod & + & - & + & + & - & +++ \\
\hline $\mathbf{P 4}$ & Short/irregular rod & + & - & + & + & - & +++ \\
\hline P5 & Rod & + & - & + & + & + & + \\
\hline P6 & Short rod & + & - & + & + & + & ++ \\
\hline P7 & Rod & - & - & + & + & - & +++ \\
\hline P8 & Short/irregular rod & + & + & + & + & + & +++ \\
\hline P9 & Short/irregular rod & + & - & + & + & + & ++ \\
\hline P10 & Short/irregular rod & + & - & + & + & - & ++ \\
\hline P11 & Short/branched rod & + & - & + & + & - & + \\
\hline P12* & Rod & - & n.d. & + & + & + & + \\
\hline $\mathrm{P} 3^{*}$ & Rod & - & n.d. & + & + & + & n.d. \\
\hline $\mathbf{P}^{*} 4^{*}$ & Rod & - & n.d. & + & + & + & - \\
\hline
\end{tabular}

Gram + = Gram positive; Gram - = Gram negative; Bacterial growth at 4, 20, $28^{\circ} \mathrm{C}$ in aerobiosis and in anaerobiosis at $28^{\circ} \mathrm{C}:(-)=$ absent, $(+)=$ present; urease activity $(+)=$ trace, $(++)=$ good, $(+++)=$ very good; n.d.= not determined. * Strains P12, P13 and P14, from the fourth purification step of strain P5, were recovered and characterized after the loss of P5.

All the bacterial isolates formed rod-shaped cells with different length, sometimes irregular or branched. The results of morphological characterization also showed the prevalence (64\%) of Gram-positive bacteria; only strains P2, P7, P12, P13 and P14 were Gram-negative. This prevalence is in line with the results of previous works $[6,8]$. It is known from the literature that Gram-positive bacteria are the predominant bacteria in the soil: only coryneform bacteria of the genus Arthrobacter alone account for approximately $20-25 \%$ of the soil cultivable bacterial population [62]. However, Gram-negative bacteria tend to be more abundant in rhizospheric soil compared to the bulk soil. Gram-negative bacteria biomass increases when rapidly decomposable $C$ compounds (such as sugars, organic and amino acids) are available [63], whereas higher proportions of Gram-positive bacteria are usually found in resource-limited area [64, 65].

Strain P8 showed growth capacity at all three tested temperatures, all other strains grew only at 20 and $28^{\circ} \mathrm{C}$. Strains P5, P6, P8, P9, P12, P13 and P14 showed growth also in anaerobiosis and are therefore considered facultative anaerobes. The use of facultative anaerobic bacteria is fundamental for soil biocementation in situ, as in the soil co-exist aerobic and anaerobic microzones [66].

All the strains were catalase positive. Apart from the strain P14 (urease negative) and P13 (not determined), all the calcifying bacteria hydrolyzed urea. This result is in accordance with the literature, since urea production, even in the presence of a significant amount of ammonium, is a common feature among soil bacteria. Urea hydrolysis producing ammonia, increases $\mathrm{pH}$ and leads to the production of carbonates. This 
means that the application of stimulated biocalcification, based on the urea hydrolysis by native or selected (in the laboratory) microbial strains, is potentially useful in a variety of soil bio-engineering applications [67].

During the characterization stage, strain P5 showed serious growth problems and was replaced by strains P12, P13 and P14, from its fourth purification step. These strains were used along this study as a mixed calcifying culture, named M5, containing in a similar proportion the strains P12, P13 and P14.

\subsection{Identification of the calcifying bacterial strains}

By the Biolog identification system, all the Gram-positive short/pleomorphic rod isolates were identified as coryneform bacteria, and Clavibacter agropyri was the most common (Tables 3 and 4).

Table 4. Identification of the calcifying bacterial isolates.

\begin{tabular}{|c|c|c|}
\hline Strain & Identified species & $\%$ ID \\
\hline P1 & Not identified & \\
\hline P2 & Vibrio tubiashii & 94 \\
\hline P3 & $\begin{array}{l}\text { Clavibacter agropyri } \\
\text { (corynebacterium) }\end{array}$ & 93 \\
\hline $\mathbf{P 4}$ & $\begin{array}{l}\text { Clavibacter agropyri } \\
\text { (corynebacterium) }\end{array}$ & 73 \\
\hline P6 & Corynebacterium urealyticum & 78 \\
\hline P7 & Not identified & \\
\hline P8 & $\begin{array}{l}\text { Clavibacter agropyri } \\
\text { (corynebacterium) }\end{array}$ & 87 \\
\hline P9 & $\begin{array}{l}\text { Clavibacter agropyri } \\
\text { (corynebacterium) }\end{array}$ & 73 \\
\hline P10 & $\begin{array}{l}\text { Clavibacter agropyri } \\
\text { (corynebacterium) }\end{array}$ & 87 \\
\hline P11 & Sanguibacter suarezii & 98 \\
\hline P12 & Sphingomonas sanguinis & 98 \\
\hline P13 & Not identified & \\
\hline P14 & $\begin{array}{c}\text { Pseudomonas syringae } \\
\text { po persicae }\end{array}$ & 92 \\
\hline
\end{tabular}

$\%$ ID = Identification index.

Isolates P3, P4, P8, P9 and P10, identified as Clavibacter agropyri (Corynebacteria), were Gram-positive rod-shaped cells, often disposed to an angle to each other giving irregular forms (Table 3). The genus Clavibacter contains plant pathogenic coryneform bacteria, causing gummosis, characterized by the presence of 2,4-diaminobutyric acid as a cell wall component [68-70]. Strain P6, a facultative anaerobic Gram-positive bacterium with good urease activity, was identified as Corynebacterium urealyticum. The aerobic Gram-positive strain P11 was identified as Sanguibacter suarezii, a coryneform bacterium first isolated from blood animal samples [71]. Coryneform bacteria are widespread in nature, being common inhabitants of water and soil, where they form alone approximately $20-25 \%$ of the soil fertile cultivable bacterial population [62]. They may be pathogens or commensals of humans, animals and plants. This ecological diversity is matched by their wide range of biochemical properties making them an interesting group of bacteria for biotechnology purposes. Among the Gram-negative isolates, strain P2 was identified by the Biolog system as Vibrio tubiashii (\% PROB $=94$ ). The genus Vibrio, includes a great diversity of species that are common inhabitants of the aquatic environment where they are usually closely associated with many kinds of marine organisms [72]. V. tubiashii is a halophilic species, firstly isolated by Tubiash et al. [73], pathogenic for the larvae of bivalve mollusks. Its genome consists of two chromosomes, two megaplasmids and two plasmids. This might be a survival strategy acquired by the Vibrios that has facilitated their adaptation to various niches, including soil environments, in 
the evolution process [74, 75]. Strains P12 and P14 were identified as Sphingomonas sanguinis and Pseudomonas syringae, respectively. Due to their biodegradative and biosynthetic capabilities, both of them have been used for a wide range of biotechnological applications. Strains P1, P13 and P7 were not identified (Table 4). The composition of the cultivable component of the microbial community living in the rhizospheric soil of Pinus strobus, showed the presence of a wide range of bacteria from diverse phylogenetic affiliation mainly Actinobacteria, Alphaproteobacteria and Gammaproteobacteria. No other attempts were made to identify the isolated bacterial species as our attention was directed towards the optimization of the process stage for isolating and screening of effective calcifying bacteria.

\subsection{Calcification and $\mathrm{CaCO}_{3}$ solubilization activities}

Observation of pure solid bacterial cultures under light microscopy, showed that $100 \%$ of the bacterial isolates were capable of forming crystalline $\mathrm{CaCO}_{3}$ on $\mathrm{B} 4$ agar plates at $20^{\circ}$ and $28^{\circ} \mathrm{C}$ (Table 5). This result confirms that: i) biomineralization leading to $\mathrm{CaCO}_{3}$ deposits is a quite common phenomenon in natural habitats [1-15]; ii) the rhizospheric soil is a good source for efficient isolation of calcifying bacteria as karst caves and secondary carbonate soils; iii) nutrient availability is a critical factor affecting microbial metabolism and precipitation activity [27]; iv) the efficiency of the Biolog EcoPlate system as a tool for estimating calcification potentiality of environmental bacterial communities [60]; v) the importance of bacterial calcification as a detoxification process (calcification by bacterial species may be an important phenotype for survival in high calcium environments as the studied soil - Table 1).

Table 5 shows the calcification parameters of the bacterial isolates: number of days required to start precipitation of $\mathrm{CaCO}_{3}$ in $\mathrm{B} 4$ agar cultures at 4,20 , and $28^{\circ} \mathrm{C}$, position on $\mathrm{B} 4$ agarized medium of the deposited crystals, amount and size of the crystals visually established by the microscope, presence of bioliths aggregates and mineralization ability in liquid B4 medium.

Table 5. Calcification parameters of the bacterial isolates.

\begin{tabular}{|c|c|c|c|c|c|c|c|c|c|}
\hline \multirow[b]{2}{*}{ Strain } & \multicolumn{3}{|c|}{ Timing ${ }^{a}$} & \multirow{2}{*}{$\begin{array}{c}\text { Position }^{\mathrm{b}} \\
28^{\circ} \mathrm{C}\end{array}$} & \multirow{2}{*}{$\begin{array}{l}\text { Shape } \\
28^{\circ} \mathrm{C}\end{array}$} & \multirow{2}{*}{$\begin{array}{l}\text { Size } \\
28^{\circ} \mathrm{C}\end{array}$} & \multirow{2}{*}{$\begin{array}{c}\text { Amount }^{\mathrm{c}} \\
28^{\circ} \mathrm{C}\end{array}$} & \multirow{2}{*}{$\begin{array}{c}\text { Aggregates } \\
28^{\circ} \mathrm{C}\end{array}$} & \multirow{2}{*}{$\begin{array}{c}\text { Liquid media } \\
28^{\circ} \mathrm{C}\end{array}$} \\
\hline & $4^{\circ} \mathrm{C}$ & $20^{\circ} \mathrm{C}$ & $28^{\circ} \mathrm{C}$ & & & & & & \\
\hline P1 & - & 30 & 14 & In/Out & $\mathrm{G} / \mathrm{O}$ & $\mathrm{M} / \mathrm{L}$ & +++ & + & + \\
\hline P2 & - & 13 & 8 & In/Out & $\mathrm{P} / \mathrm{O}$ & $\mathrm{S} / \mathrm{M}$ & ++++ & +++ & + \\
\hline P3 & - & 20 & 8 & In/Out & G & $\mathrm{M} / \mathrm{L}$ & +++ & ++ & ++ \\
\hline P4 & - & 23 & 10 & In/Out & G & $\mathrm{L}$ & +++ & + & - \\
\hline P5 & n.d. & n.d. & n.d. & In/Out & $\mathrm{G} / \mathrm{O}$ & $S$ & + & - & n.d. \\
\hline $\mathbf{M}^{\mathrm{d}}$ & - & 16 & 14 & In/Out & $\mathrm{G} / \mathrm{O}$ & S & ++++ & ++ & - \\
\hline P6 & - & 11 & 8 & In & $\mathrm{G} / \mathrm{P}$ & $\mathrm{M} / \mathrm{L}$ & ++++ & ++ & +++ \\
\hline P7 & - & 8 & 4 & In/Out & G & $\mathrm{L}$ & ++ & ++ & - \\
\hline P8 & 20 & 8 & 8 & In/Out & $\mathrm{G} / \mathrm{P}$ & $\mathrm{S} / \mathrm{L}$ & ++ & + & ++ \\
\hline P9 & - & 22 & 10 & In/Out & G & $\mathrm{M} / \mathrm{L}$ & ++++ & $++/+++$ & - \\
\hline P10 & - & 13 & 8 & In & $\mathrm{G} / \mathrm{P}$ & $\mathrm{S} / \mathrm{M} / \mathrm{L}$ & ++ & - & + \\
\hline P11 & - & 12 & 8 & In/Out & $\mathrm{G} / \mathrm{P}$ & $S$ & +++ & $+/++$ & + \\
\hline
\end{tabular}

aTiming: number of days required to start precipitation of $\mathrm{CaCO}_{3}$ in $\mathrm{B} 4$ agar cultures at 4,20 , and $28^{\circ} \mathrm{C}$;

bPosition on B4 agarized medium of the deposited crystals (inside and/or outside the bacterial colony);

c visually established by the microscope;

d M5 is a mixed calcifying culture composed by the strains P12 (Sphingomonas sanguinis), P13 (not identified) and P14 (Pseudomonas syringae);

n.d. = not determined; In = inside the colony; Out = outside the colony; In/Out = inside and outside the colonies;

$\mathrm{G}=$ globular, spheric; $\mathrm{O}=$ oval; $\mathrm{P}=$ prismatic; $\mathrm{S}=$ small-sized; $\mathrm{M}=$ medium-sized $(80-100 \mu \mathrm{m}) ; \mathrm{L}=$ large-sized $(100-200 \mu \mathrm{m}) ; \mathrm{CaCO} 3$ 
deposition: $(-)$ = absent, $(+)=$ trace, $(++)=$ good,$(+++)=$ very good $(++++)=$ excellent .

At $28^{\circ} \mathrm{C}, \mathrm{CaCO}_{3}$ formation took place rapidly and all the calcifying bacteria began to precipitate within two weeks (Table 5): high temperatures resulted in faster bacterial growth and thus, higher acetate consumption. Vice versa, at lower temperatures bacterial metabolism slows down and resulted, for instance, in slow rates of $\mathrm{pH}$ change and acetate consumption. In fact, when bacteria were cultivated at $20^{\circ} \mathrm{C}$, the time required for crystal precipitation was longer and all the calcifying isolates began to precipitate within four weeks (Table 5). Apart from strain P8, which precipitated after three weeks, bacterial growth and crystal deposition was not observed at $4^{\circ} \mathrm{C}$.

The microscopic observation showed that at $28^{\circ} \mathrm{C}, \mathrm{CaCO}_{3}$ precipitation always takes place inside the bacterial colony and often in the immediate vicinity and/or in the culture medium, that is in a microenvironment conditioned by the direct presence of the cells. This means that for the deposition of $\mathrm{CaCO}_{3}$ the presence of crystallization nuclei is not sufficient, but the role of microbial metabolism is necessary. No crystal formation was observed in uninoculated control plates. This confirms that $\mathrm{CaCO}_{3}$ deposition was to be attributed to the bacterial cells.

Table 5 shows that, apart from strain P2 that deposited prismatic and oval crystals, all others strains deposited spherical crystals, as the only prevalent typology. About the size, $66.6 \%$ of the calcifying cultures deposited large-sized crystals (P1, P3, P4, P6, P7, P8, P9 and P10). Strains P2, P5, P11 and the mixed culture M5, precipitated crystals of smaller dimensions (Table 5). Regarding the amount of precipitated crystals, the most active cultures in calcification, were strains P1, P2, P3, P4, P6, P9 and P11 (Table 5). The remaining strains (P7, P8 and P10) showed quantitative characteristics of intermediate precipitation.

Strains with the larger amount of precipitates were also those that gave rise to more $\mathrm{CaCO}_{3}$ aggregates (Table 5). Based on microscopic observation of the calcifying solid cultures, the mixed culture M5 produced larger crystal aggregates than the pure cultures of its constituent strains P12, P13, and P14. Actually, bacteria always live in bio-diversified community, metabolically interacting, thus extending their survival through cometabolism. This is one of the reasons why it is sometimes preferable to use mixed calcifying cultures.

Strain P6, identified as Corynebacterium urealyticum, precipitates the largest amount of crystals in B4 liquid medium (Table 5). Strains P3 and P8, identified as Clavibacter agropyri, showed a good precipitation ability in liquid B4 medium. P1, P2, P10 and P11, showed very poor ability to precipitate in B4 medium; while P4, P7, P9 and the mixed culture M5 showed no precipitation activity in liquid medium (Table 5).

All the calcifying cultures showed carbonate-solubilization ability when grown on $0.14 \% \mathrm{CaCO}_{3}$, after four weeks of incubation at $28^{\circ} \mathrm{C}$ (Table 6). Vibrio tubiashii (P2), Clavibacter agropyri (P3, P10), the not identified strains P1 (Figure 3) and P7 being particularly effective. 
Table 6. Solubilization activity of the calcifying bacterial cultures obtained from a rhizospheric soil (L'AquilaCentral Italy).

\begin{tabular}{|c|c|c|c|}
\hline \multirow[t]{2}{*}{ Strains } & \multirow[t]{2}{*}{ Identified species } & \multicolumn{2}{|c|}{ Solubilization } \\
\hline & & $\mathrm{CaCO}_{3}(0.14 \%)$ & $\mathrm{CaCO}_{3}(2.5 \%)$ \\
\hline P1 & Not identified & +++ & $+/-{ }^{a}$ \\
\hline P2 & Vibrio tubiashii & +++ & $+/-$ \\
\hline P3 & $\begin{array}{l}\text { Clavibacter agropyri } \\
\text { (corynebacterium) }\end{array}$ & +++ & $+/++$ \\
\hline $\mathbf{P 4}$ & $\begin{array}{l}\text { Clavibacter agropyri } \\
\text { (corynebacterium) }\end{array}$ & ++ & ++ \\
\hline M5 & $\begin{array}{l}\text { Sphingomonas sanguinis } \\
\text { (P12), Not identified (P13), } \\
\text { Pseudomonas syringae (P14) }\end{array}$ & ++ & + \\
\hline P6 & $\begin{array}{c}\text { Corynebacterium } \\
\text { urealyticum }\end{array}$ & ++ & ++ \\
\hline P7 & Not identified & +++ & $+/++$ \\
\hline P8 & $\begin{array}{l}\text { Clavibacter agropyri } \\
\text { (corynebacterium) }\end{array}$ & ++ & $+/-$ \\
\hline P9 & $\begin{array}{l}\text { Clavibacter agropyri } \\
\text { (corynebacterium) }\end{array}$ & ++ & - \\
\hline P10 & $\begin{array}{l}\text { Clavibacter agropyri } \\
\text { (corynebacterium) }\end{array}$ & +++ & + \\
\hline P11 & Sanguibacter suarezii & ++ & + \\
\hline
\end{tabular}

Apart from strain P9, identified as Clavibacter agropyri, which do not dissolve detectable amounts of carbonate, all the calcifying strains showed poor $\mathrm{CaCO}_{3}$ solubilization ability, when grown on $2.5 \% \mathrm{CaCO}$ (Table 6). Three calcifying cultures (P1, P2 and M5) showed spotted solubilization (Table 6 and Figure 4). The mixed calcifying culture M5 showed solubilization activity in a lesser extent than expected.

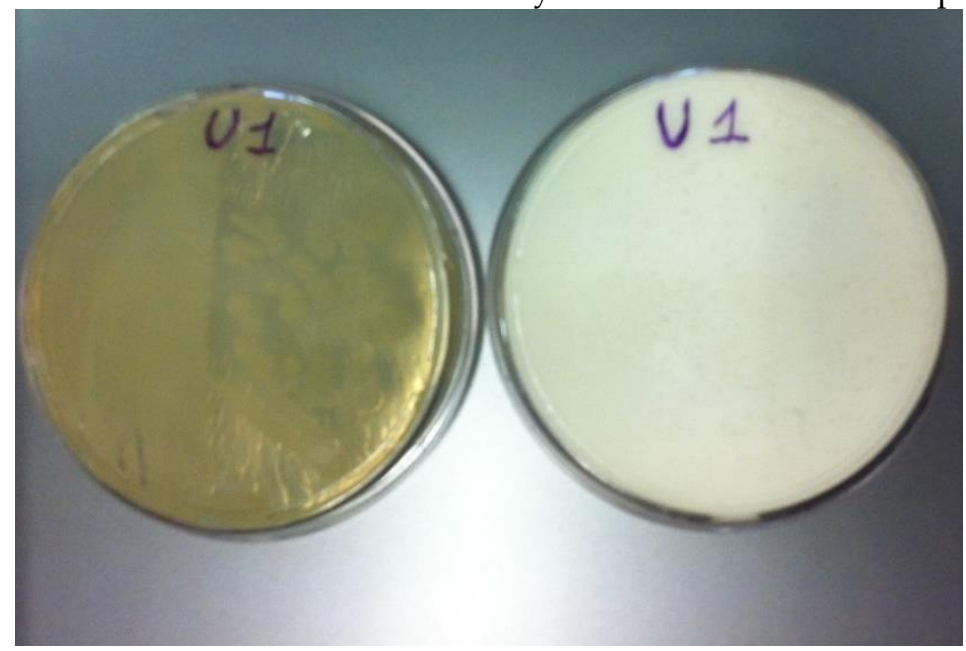

Figure 4. $\mathrm{CaCO}_{3}$ solubilization, after 30 days incubation at $28^{\circ} \mathrm{C}$, by the not identified strain $\mathrm{P} 1$, firstly named $\mathrm{U} 1$. Note that the solubilization is almost complete at $0.14 \%$ (left), and as spots at $2.5 \% \mathrm{CaCO}_{3}$ (right). 


\subsection{Bacterial calcification activity by the ImageJ software}

It is possible to evaluate the $\mathrm{CaCO}_{3}$ precipitation efficiency of a calcifying strain taking into account different calcification parameters such as: i) time required to initiate precipitation, ii) abundance of the precipitated crystals (which is related to the precipitation rate of the calcifying strain), iii) crystal size, iv) presence of crystal aggregates and v) $\mathrm{CaCO}_{3}$ solubilization activity. The use of the ImageJ software allowed us to obtain a very effective BCP index, referred in this paper as "extent" (i.e. calcification level as percent average surface occupied by $\mathrm{CaCO}_{3}$ crystals biodeposited on an agarized medium). The $\mathrm{BCP}$ extent, depending on all the calcification parameters mentioned above, allows to test in a single step the calcification aptitude of each bacterial strain, optimizing the screening program.

Figure 5 shows the percent average surface occupied by $\mathrm{CaCO}_{3}$ crystals precipitated by the calcifying bacterial cultures, after 30 days of growth on $\mathrm{B} 4$ agar, at $28^{\circ} \mathrm{C}$.

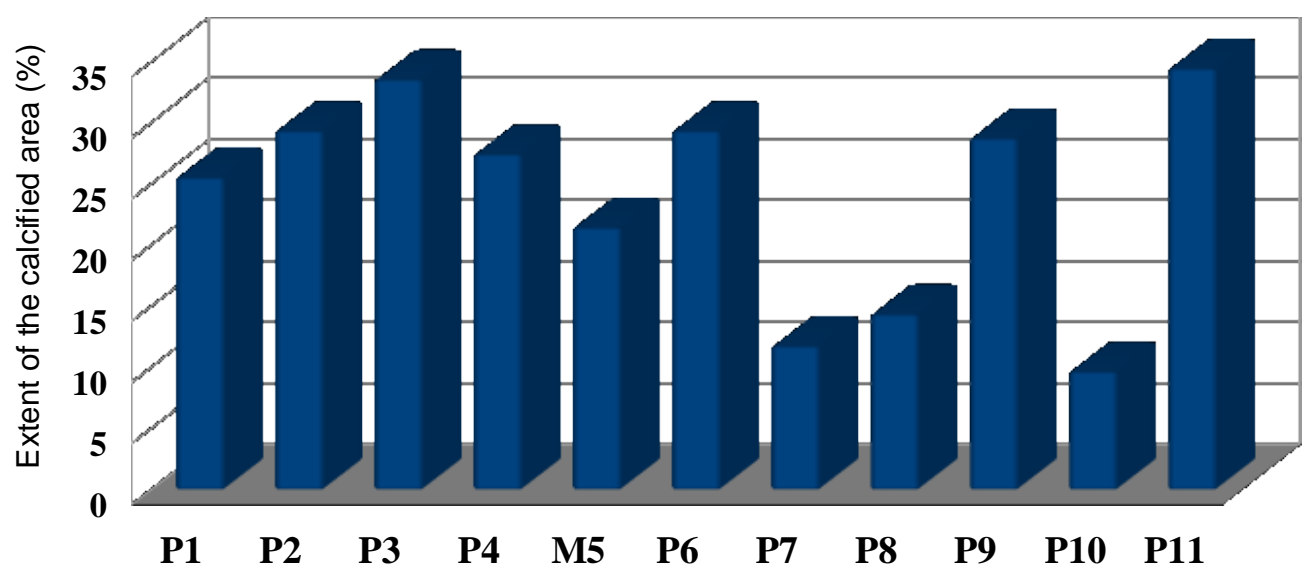

Bacterial cultures

Figure 5. Percent average surface (BCP extent) occupied by the $\mathrm{CaCO}_{3}$ crystals precipitated in vitro by the pure and mixed calcifying cultures, after 30 days of growth on $\mathrm{B} 4$ agar at $28^{\circ} \mathrm{C}$ (the BCP-extent values were obtained through ImageJ software).

Two groups of calcifying strains were identified on the basis of their calcification ability in terms of extent (\%) of the biocemented area: a group of very highly active BCP bacteria, with percent average surface occupied by $\mathrm{CaCO}_{3}$ crystals greater than $25 \%$ and group of less active bacteria with $\mathrm{CaCO}_{3}$ percent average surface less than $25 \%$. The calcifying strains belonging to the first group were strains P2 (Vibrio tubiashii), P3, P4 and P9 (all three Clavibacter agropyri), P6 (Corynebacterium urealyticum), and P11 (Sanguibacter suarezii). All these bacterial strains produced in vitro $\mathrm{CaCO}_{3}$ crystals abundant and medium/large sized, apart from strain P6 that formed smaller crystals (Table 5). They also showed a good aptitude to form large aggregates and vice versa a poor or absent $\mathrm{CaCO}_{3}$ solubilization activity (Tables 5 and 6).

\subsection{Calcifying strain selection for sand biocementation}

Calcifying cultures for sand biocalcification experiments on Petri dish, were selected base on their morpho-physiological traits (Table 3) and calcification parameters (Tables 5, 6 and Figure 5), as stated in Materials and Methods.

Among bacterial strains with BCP extent greater than 25\% (Figure 5), we selected: i) strain P2, identified as Vibrio tubiashii, being the only one to have a not branched or irregular shape of the cell (Table 3). Short rods are certainly to be preferred compared to medium, long or branched rods because of their greater possibility of penetration into the ground; ii) strain P9, Clavibacter agropyri, for both the ability to growth in the absence of oxygen (Table 3) and its no solubilization activity of $\mathrm{CaCO}_{3}$ at $2.5 \%$ (Table 6). Facultative anaerobes are preferred because of their tolerance for the restricted availability of oxygen that can be encountered in subsurface environments; this ability is fundamental because aerobic and anaerobic microzones coexist in the 
soil, since anaerobic conditions are abundant, particularly when the rain saturates the soil and gas exchange slows down almost completely [66]; and iii) strain P11, identified as Sanguibacter suarezii, Gram-positive. Gram-positive bacteria are preferable to Gram-negative ones for their thicker wall, which makes them more resistant to changes in osmotic pressure, which is a typical condition for soil under consolidation or in recovery phase [66]. The mixed calcifying culture M5, belonging to the second group (Figure 5), was also included in the biocementation experiments.

After 20 days of biotreatment (at $28^{\circ} \mathrm{C}$, under static conditions) there was complete cementation of all the pre-treated sand samples (Figure 6). 


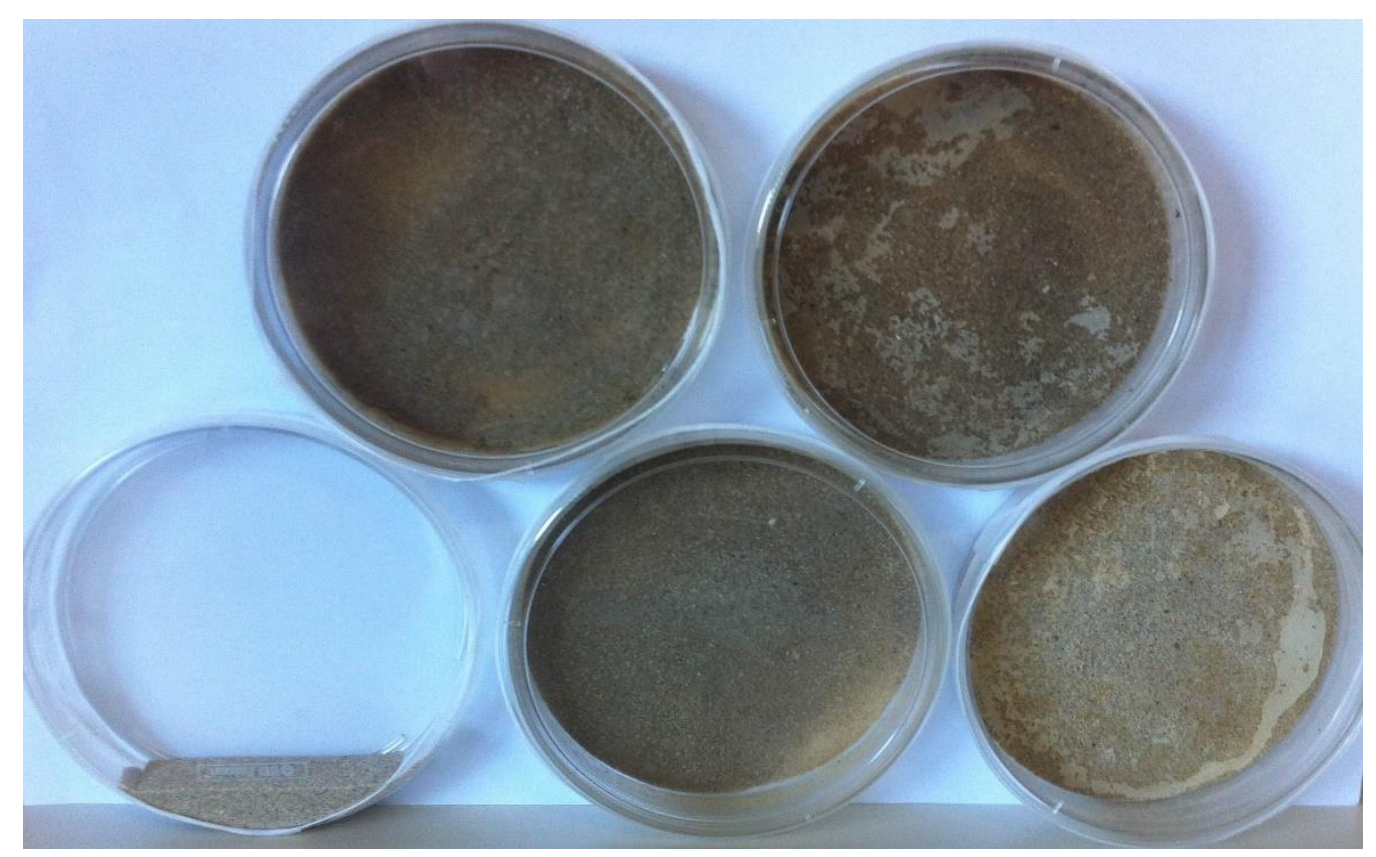

Figure 6. Samples of biocemented sand through $\mathrm{CaCO}_{3}$ precipitation by strains P2, P11, M5 and P9 (starting from the upper left to the lower right) after 20 days of incubation, at $28^{\circ} \mathrm{C}$. Untreated control at the left bottom. The plates were positioned vertically to highlight the biocementation of the sand, not present in the control.

No signs of calcification were observed on the sand sample not biotreated (Figure 6). This showed that the cementing action of the sand particles was to be attributed to the bacterial cells.

Strain P6 (Corynebacterium urealyticum), belonging to the first group of calcifying strains (Figure 5), was selected for deep sand biocementation base on its capability to precipitate $\mathrm{CaCO}_{3}$ crystals in liquid B4 medium, to hydrolyze urea and to grow in anaerobiosis (Tables 3 and 5). The results obtained after one week (on the left) and two months (on the right) of treatment are shown in Figure 7.

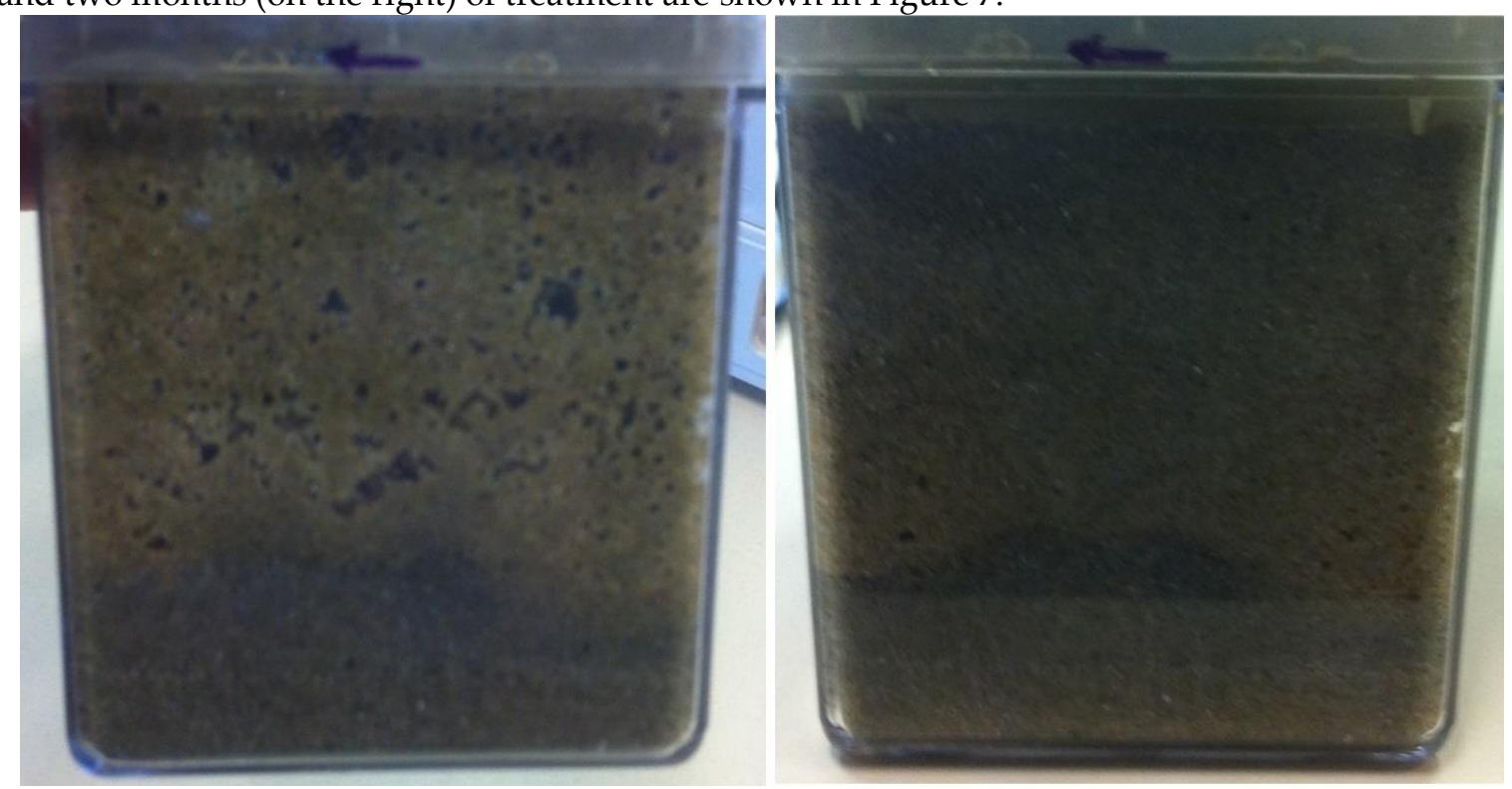

Figure 7. Test for deep biocementation of $300 \mathrm{~g}$ of sea sand in Magenta vessel $(60 \mathrm{~mm} \times 60 \mathrm{~mm}$ and $50 \mathrm{~mm}$ height), by strain P6 (Corynebacterium urealyticum) grown on B4 liquid medium. On the left the sample after a week of treatment, on the right the sand-sample after two months of treatment (note the complete occlusion of visible pores by the biodeposition of $\mathrm{CaCO}_{3}$ crystals).

After the biotreatment, the sand samples did not reach a cementation level sufficient to be subjected to the shear strength test, even in the presence of urea, calcium chloride and low clay fraction [38, 39]. 
Optimization of the deep biocementation experiments, fallowing outside the objectives of this work, has not been carried out.

\subsection{SEM, XRD and EDS analyses}

SEM observations were carried out to study the morphological characteristics of the biominerals precipitated and the involvement of bacteria in calcite biomineralization. A variety of crystal shapes were observed. The most frequent were single irregular spheres (Figure 8a, c, d, e, f), hemispheres (Figures 8a, e) and their irregular aggregates (Figure 8e, in particular). Most of the formed crystals had rough surfaces. SEM investigation also revealed the presence of bacterial cells in close contact with $\mathrm{CaCO}_{3}$ crystals (Figures $8 \mathrm{a}$, c, $\mathrm{d}$ and $\mathrm{f}$, in particular). The presence of $\mathrm{CaCO}_{3}$ associated with bacteria proves that bacteria served as nucleation sites during the mineralization process.
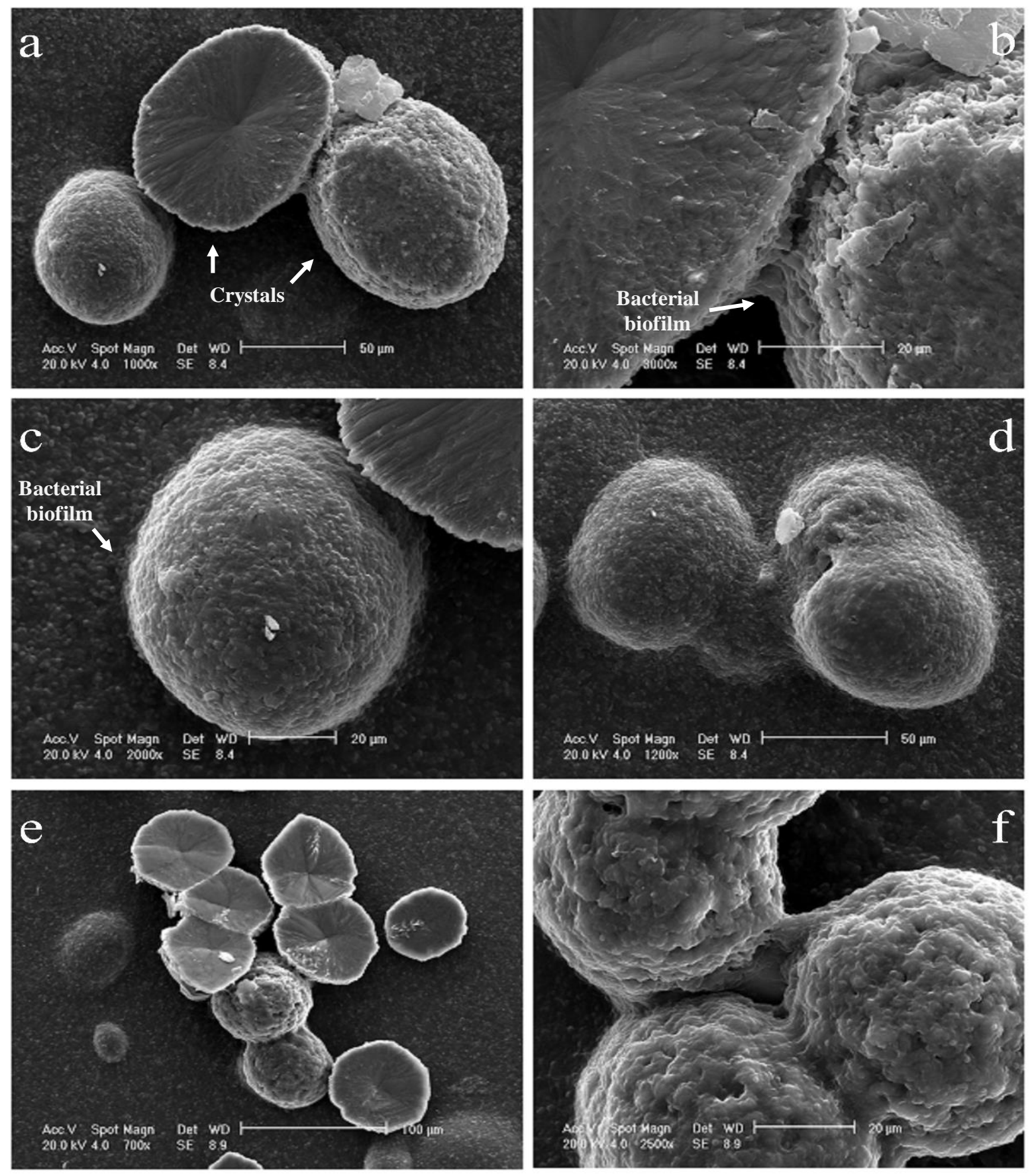

Figure 8. Scanning electron micrograph of $\mathrm{CaCO}_{3}$ crystals and calcite aggregates deposited in vitro on agarized B4, at $28^{\circ} \mathrm{C}$ by rhizospheric strains P1 (unidentified) (a, b, c, d) and P2 (Vibrio tubiashii) (e, f). a) Bioliths, spherical and hemispherical; magnification $50 \mu \mathrm{m}$. b) Enlargement of $\mathbf{a}$, contact zone between two bioliths, during the 
aggregation phase, showing a bridge formed by biofilm and $\mathrm{CaCO}_{3}$ crystals of neo-deposition; $20 \mu \mathrm{m}$ magnification. c) Enlargement of a, observe the significant amounts of bacterial cells in the background, $20 \mu \mathrm{m}$ magnification. d) Spherical bioliths completely immersed in the microbial biofilm, $50 \mu \mathrm{m}$ magnification. e) Aggregate formed by bioliths and hemi-bioliths, surrounded by bacterial cells; $100 \mu$ m magnification. f) $\mathrm{CaCO}_{3}$ aggregate of three bioliths, note the cementing action of the microbial biofilm; $20 \mu \mathrm{m}$ magnification.

X-Ray Diffraction was carried out to identify the types of carbonate polymorph that were precipitated by the pure cultures selected for sand biocementation (P2 in Figure 9, P6, P9 and P11). In all the investigated cases, crystals precipitated by bacteria were both calcite, the rhombohedral form of $\mathrm{CaCO}_{3}$ [R-3c] (card number 5586 ), and vaterite, a hexagonal form of $\mathrm{CaCO}_{3}[\mathrm{P} 63 / \mathrm{mmc}]$ (card number 24-30).

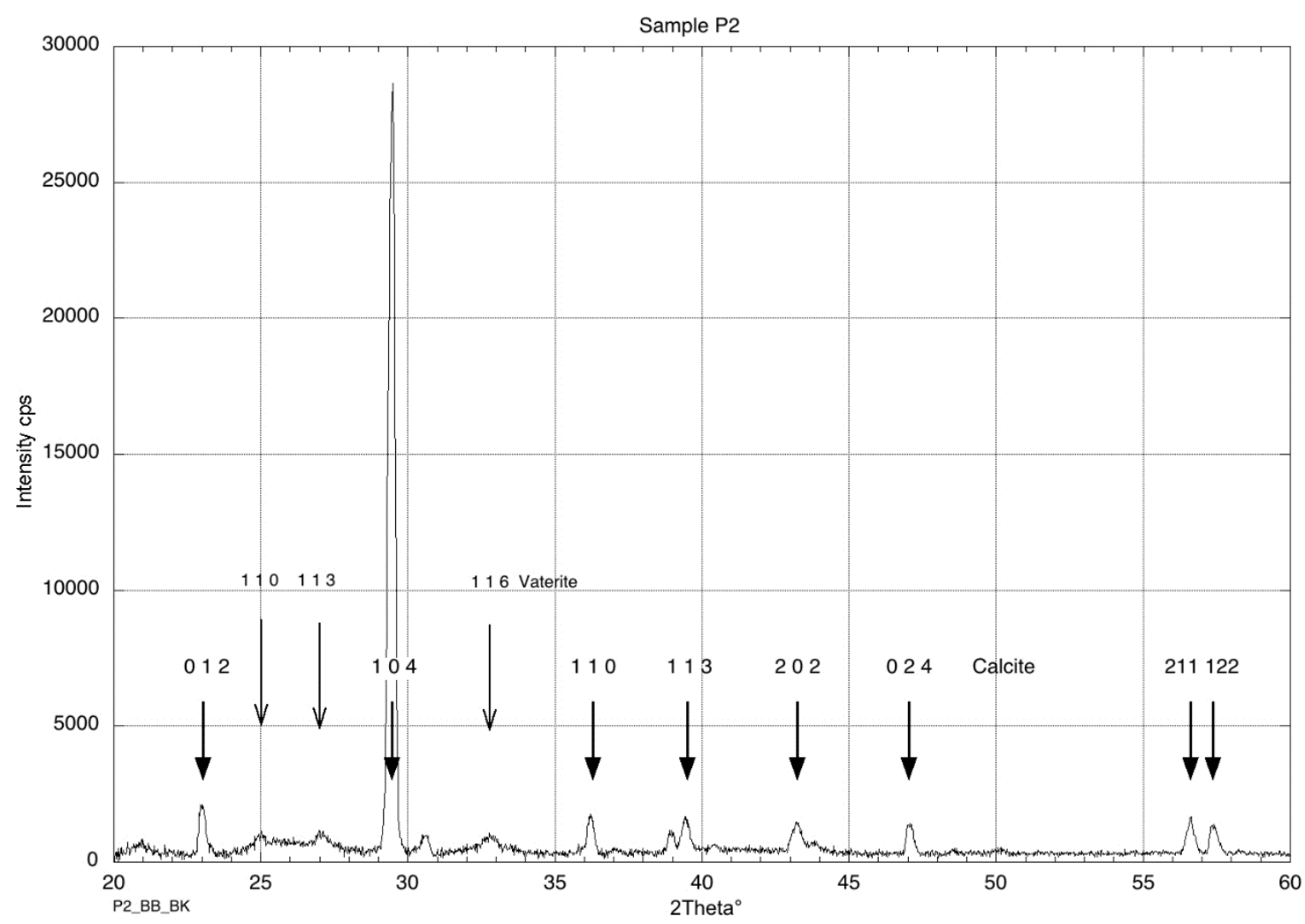

Figure 9. X-ray diffraction pattern from an agar dried culture of strain P2, Vibrio tubiashii. The spectrum shows the presence of a mixture of calcite and vaterite. The background level is due to the presence of the agar and of the adhesive tape.

Vaterite is the $\mathrm{CaCO}_{3}$ polymorph with a high solubility that may be prone to dissolution by meteoric water and to a low degree of consolidation, by comparison to calcite. However, it was suggested that the microbially induced vaterite achieves similar degrees of stability as calcite by incorporating organic molecules [76].

SEM and EDS analyses of the sand samples biotreated on Petri dishes (Figure 6) showed that sand compaction was due to the cementing action of $\mathrm{CaCO}_{3}$ bioliths that act as a bridge between the sand particles. The EDS spectra (Figure 10) showed $\mathrm{Ca}, \mathrm{C}$, O peaks that can be associated qualitatively with $\mathrm{CaCO}_{3}$. The presence of high carbon, calcium and oxygen peaks in the analyzed area, showed a high amount of $\mathrm{CaCO}_{3}$. SEM image in Figure 10, shows that $\mathrm{CaCO}_{3}$ crystals produced by strain $\mathrm{P} 9$, Clavibacter agropyri, coat and bridge the sand particles, cementing the matrix.

According to EDS analysis, also the untreated sand presents, besides a high content of silica and oxygen, calcium and carbon but in low amount (Figures 11). As showed by the physico-chemical analyses (Table 2) and XRD (Figure 12), organic matter is the origin of $C$, while lithogenic carbonates could be the origin of Ca identified by EDS. 


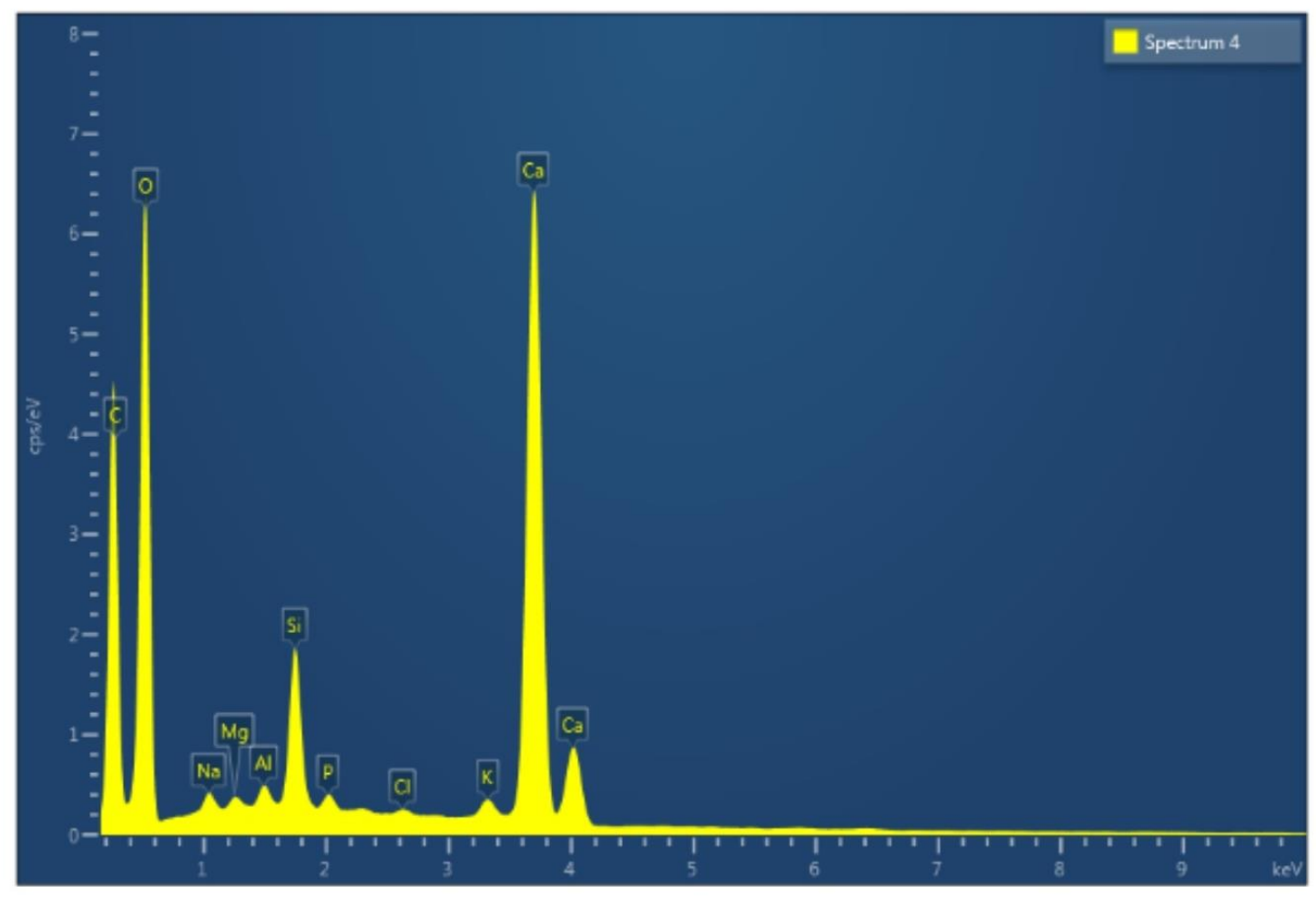

\section{Electron Image 3}

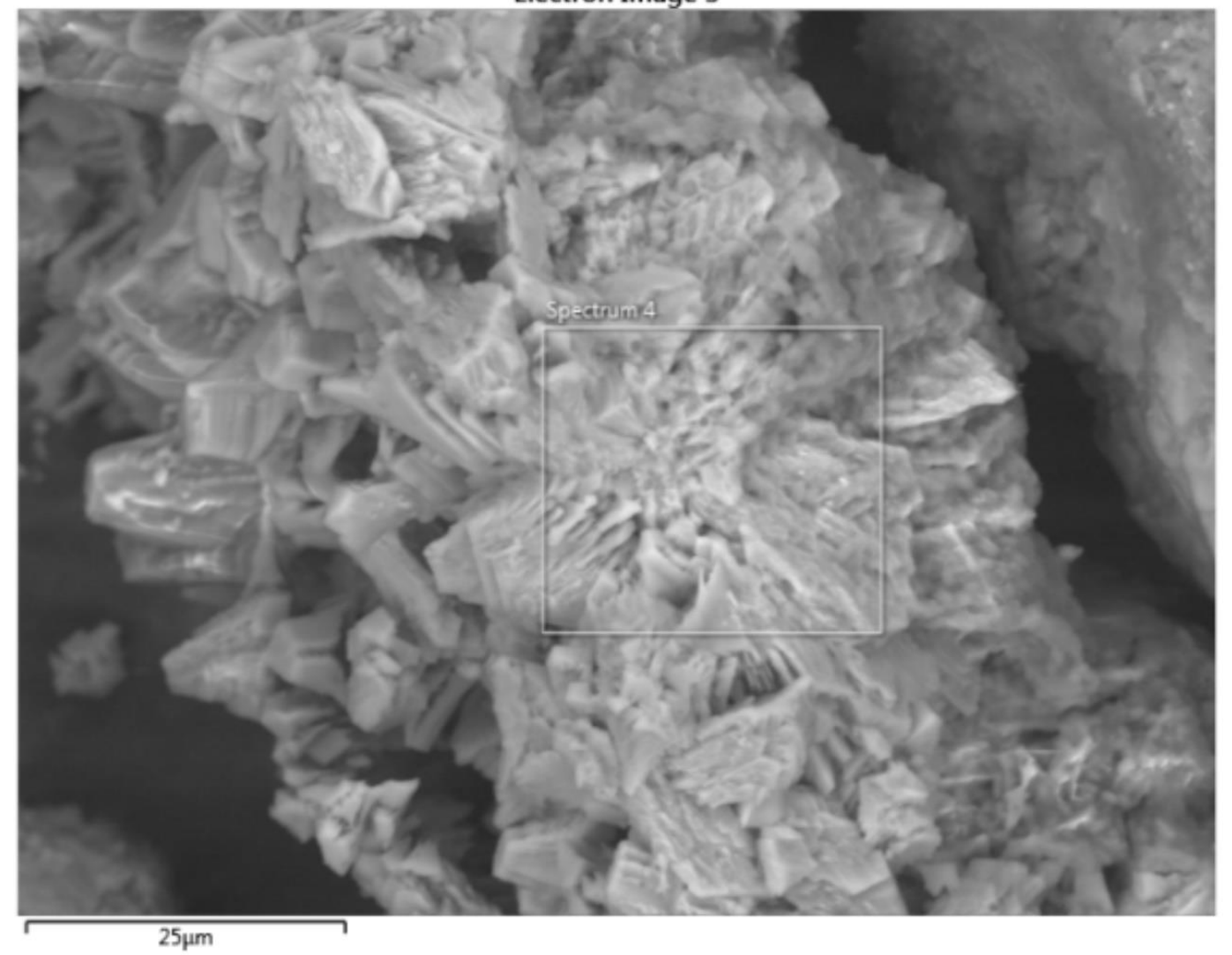

Figure 10. EDS spectrum and SEM image of the sand after 20 days of treatment at $28^{\circ} \mathrm{C}$ with the strain P9 (Clavibacter agropyri). 


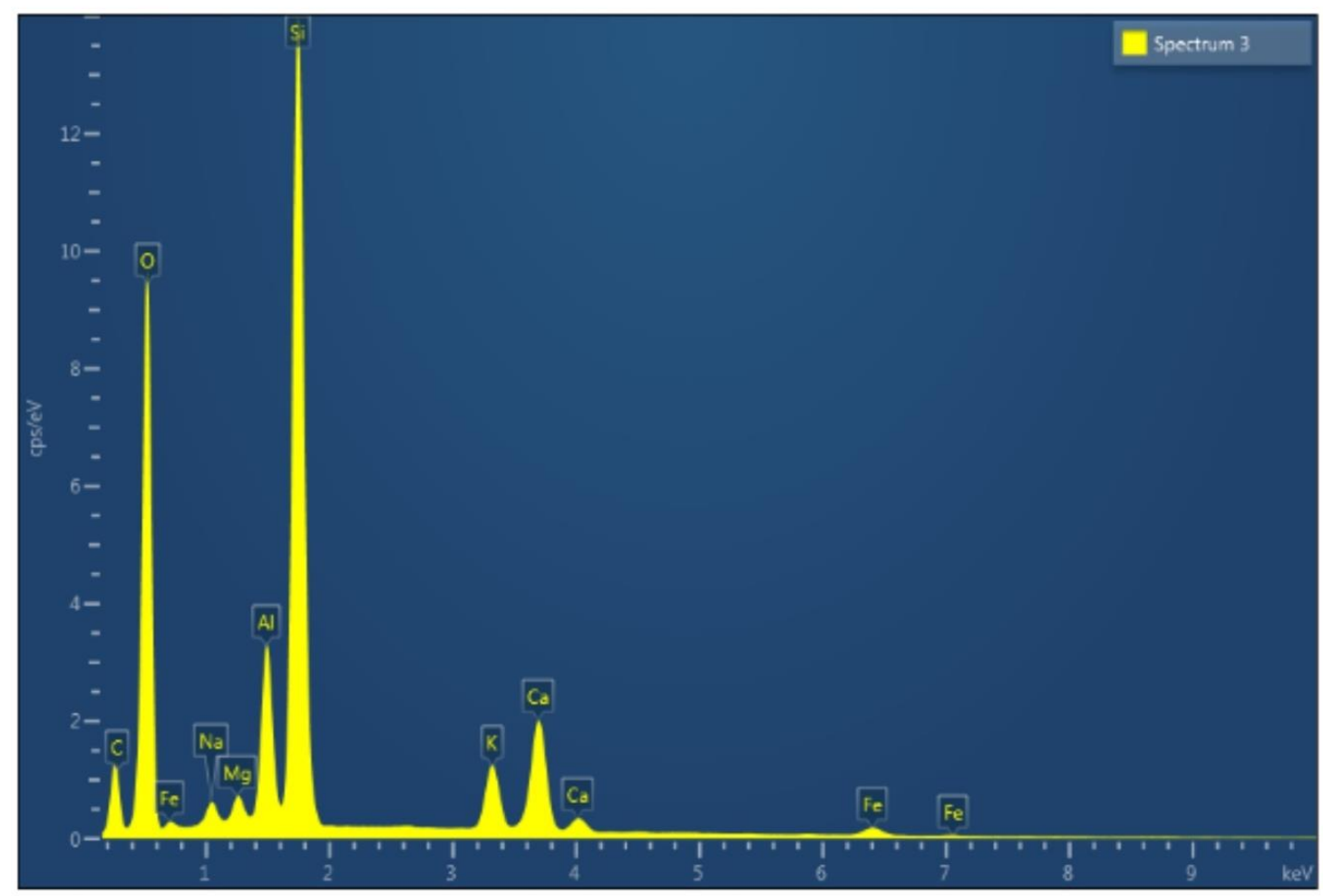

Electron Image 2

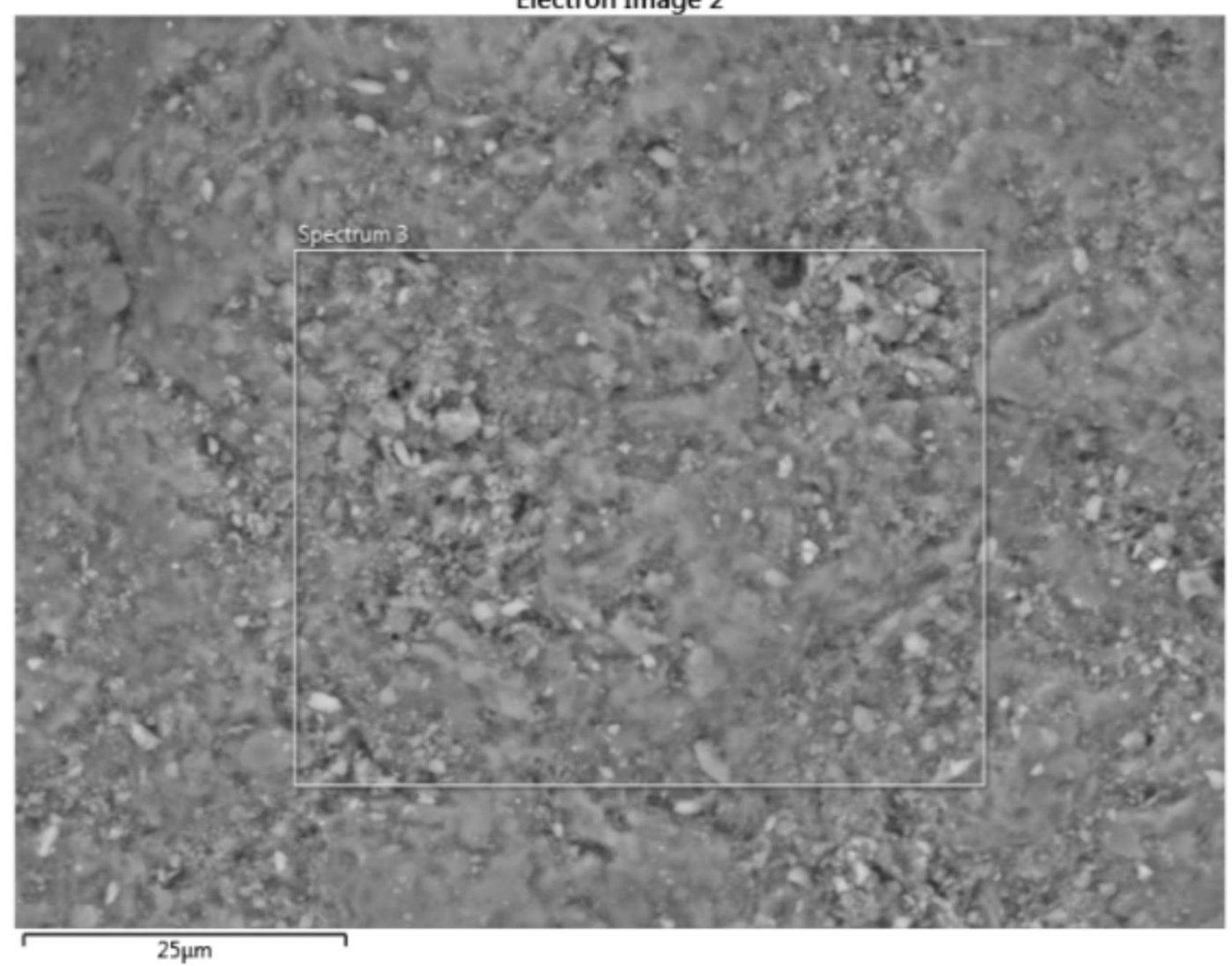

Figure 11. EDS spectrum and SEM image of the untreated sand. 


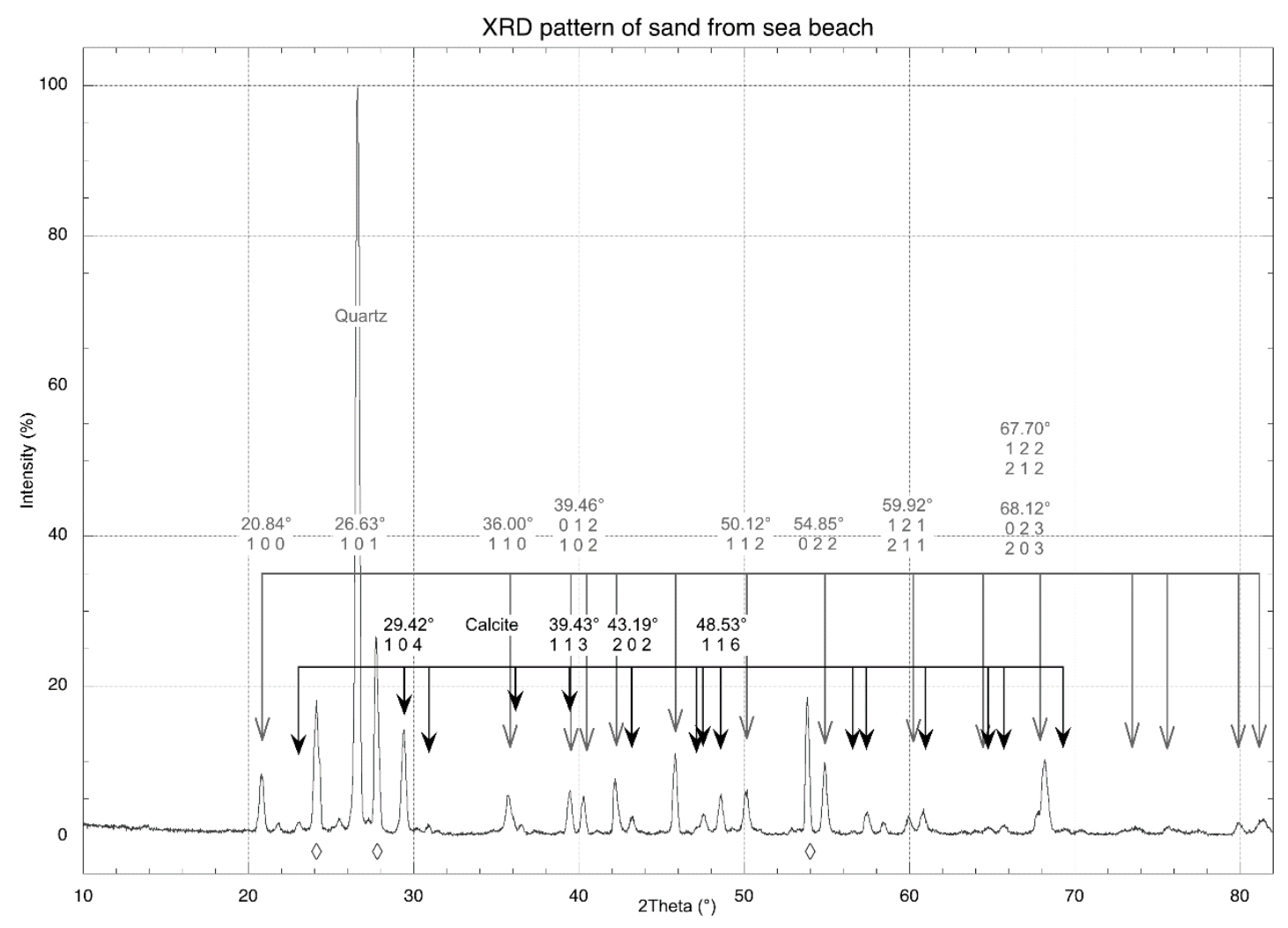

Figure 12. XRD pattern of the sea sand. The spectrum shows the prevalence of quartz and calcite.

\section{Summary and Conclusions}

Successful application of BCP in the different fields of interest, depends on a variety of factors. Much effort has been devoted to understand the factors governing BCP as well as the criteria for the selection of bacterial strains to optimize the biodeposition of $\mathrm{CaCO}_{3}$ in a variety of biotechnological applications. To date, two strategies involving bacteria capable of inducing $\mathrm{CaCO}_{3}$ precipitation have been mostly used: one in which an axenic culture is used directly for biotechnological purposes and another that utilizes the carbonatogenic potential of the autochthonous microbial communities. In this study, we adopted a novel approach based on the study (through the Biolog EcoPlates) of the BCP potential of the sampling site (a rhizospheric soil) and the use of selected (pure or mixed) calcifying cultures from this community. Until now, rhizospheric soil has been scarcely explored, with most of the studies focused on different calcium carbonate deposits in caves, freshwater and seawater. Growth and biodiversity of the rhizospheric bacteria are highly influenced by type of soil, moisture content, temperature, chemicals and above all by the plant species. Thus, choosing a proper rhizospheric soil (by knowing that microbial community dwelling the rhizospheric soil have the possibilities to perform ammonification of amino acids as well as mineralization of organic acids) it is possible to increase the screening efficiency for strong $\mathrm{CaCO}_{3}$ depositor strains, likely due to increased number of bacteria useful to induce $\mathrm{CaCO}_{3}$ precipitation. In this study, we used the B4 medium to isolate the cultivable heterotrophic calcifying microflora from the rhizospheric soil of Pinus strobus, obtaining a microbial consortium consisting exclusively of calcifying bacteria, although B4 was not a selective medium. This confirms how the combined use of Biolog EcoPlates (for a more targeted selection of the sampling site) and rhizospheric soil (as sampling site) can represent a useful tool to start a successful screening of potent calcifying cultures. To our knowledge this is the first study that shows the $\mathrm{CaCO}_{3}$ biomineralization ability of Vibrio tubiashii, Clavibacter agropyri (Corynebacterium), Corynebacterium urealyticum, Sanguibacter suarezii, Sphingomonas sanguinis and Pseudomonas syringae. As the metabolic response in the Biolog EcoPlates is at community level and involves in each well cooperative as well as competitive 
microbial behaviors, the real utility of the Biolog Ecoplates for a more targeted choice of the sampling site is conditioned by the use of mixed cultures whenever calcifying ability of the bacterial culture decreases or disappears following bacterial strain purification. Thus, it is important to preserve the $\mathrm{BCP}$ potential of the rhizospheric microbial community.

To select (pure or mixed) bacterial cultures suitable for sand biocementation, we performed an array of tests based on carbonate precipitation (i.e. $\mathrm{CaCO}_{3}$ precipitation on solid media at different temperatures or in liquid condition at $28^{\circ} \mathrm{C}$ ), carbonate solubilization as well as physiomorphological analyses. To assess the extent of calcification by each bacterial strain, we applied ImageJ software as a new method for estimating BCP in solid media. Nevertheless, the positive results we obtained both in the enrichment and in the selection of bacteria useful for sand biocementation, the approach we proposed as well as the use of the ImageJ as a screening tool, need to be further investigated and optimized.

As a future goal, we are studying the role of cell interactions, namely the occurrence of a cell-tocell communication system (quorum sensing), in the BCP process mediated by Gram-negative bacteria. Moreover, an optimization of the ImageJ method is in progress using a motorized microscope (Zeiss AXIO Imager.M2) with an Axiocam 503 camera, for the automatic choice of the visual fields and an accurate scale-bar determination and calibration.

Acknowledgements: We thank L. Giansante for his assistance during the laboratory work, M. Giammatteo and L. Arrizza for assistance with SEM, M. Pellegrini and F. Matteucci for Biolog assistance and data elaboration. We also thank M. Passacantando and G. Cappuccio for collaboration in crystal XRD-analyses and graphic assistance.

Author Contribution: Paola Cacchio conceived the research question, contribute to methodology and data curation, wrote the draft paper, contribute to revision and editing; Maddalena Del Gallo contribute to the analysis of the results, critical revision and editing of the final manuscript.

Funding: This research received no external funding.

Conflicts of Interest: The authors declare no conflict of interest

\section{References}

1. Stocks-Fischer, S.; Galinat J.K.; Bang, S.S. Microbiological precipitation of $\mathrm{CaCO}_{3}$. Soil Biol. Biochem. 1999, 31, 1563-1571. DOI 10.1016/S0038-0717(99)00082-6.

2. Banks, E.D.; Taylor, N. M.; Gulley, J.; Lubbers, B.R.; Giarrizo, J.G.; Bullen, H.A.; Hoehler, T.M.; Barton, H.A. Bacterial calcium carbonate precipitation in cave environments: a function of calcium homeostasis. Geomicrobiol. J. 2010, 27, 444-454, DOI 10.1080/01490450903485136.

3. Baskar, S.; Baskar, R.; Mauclaire, L.; Mckenzie, J. A. Role of microbial community in stalactite formation, Sahastradhara caves, Dehradun, India. Curr. Sci. 2005, 88, 1305-1308.

4. Boquet, E.; Boronat, A.; Ramos-Cormenzana, A. Production of calcite (calcium carbonate) crystals by soil bacteria is a general phenomenon. Nature 1973, 246, 527-529.

5. Braissant, O.; Cailleau, G.; Dupraz, C.; Verrecchia, E.P. Bacterially induced mineralization of calcium carbonate in terrestrial environments: the role of exopolysaccharides and amino acids. J. Sediment. Res. 2003, 73, 485-490, DOI 10.1007/s00114-002-0340-0.

6. Cacchio, P.; Ercole, C.; Lepidi, A. Calcium carbonate deposition in limestone caves: microbiological aspects. Subterr. Biol. 2003a, 1, 57-63.

7. Cacchio, P.; Ercole, C.; Cappuccio, G.; Lepidi, A. Calcium carbonate precipitation by bacterial strains isolated from a limestone cave and from a loamy soil. Geomicrobiol. J. 2003b, 20, 85-98.

8. Cacchio, P.; Contento, R.; Ercole, C.; Cappuccio, G.; Preite Martinez, M.; Lepidi, A. Involvement of microorganisms in the formation of carbonate speleothems in the Cervo Cave (L'Aquila-Italy). Geomicrobiol. J. 2004, 21, 497-509.

9. Cacchio, P.; Ercole, C.; Lepidi, A. Evidences for Bioprecipitation of Pedogenic Calcite by Calcifying Bacteria from Three Different Soils of L'Aquila Basin (Abruzzi, Central Italy). Geomicrobiol. J. 2015, 32, 701 -711.

10. Danielli, H.M.C.; Edington, M.A. Bacterial calcification in limestone caves. Geomicrobiology 1983, 3, 1-16, DOI 10.1080/01490458309377780. 
11. Lipman, C.B. Further studies on marine bacteria with special reference to the Drew hypothesis on $\mathrm{CaCO}_{3}$ precipitation on sea. Carnegie Inst. 1929, 39, 231-248.

12. Morita, R.Y. Calcite precipitation by marine bacteria. Geomicrobiology 1980, 2, 63-82.

13. Northup, D.E.; Reysenbach, A.L.; Pace, N.R. Microorganisms and speleonthems. In Cave minerals of the world, 2nd ed.; Hill, C., Forti, P., Eds.; National Speleological Society: Huntsville, Alabama, 1997; pp. 261-266; ISBN 1-879961-07-5.

14. Novitsky, J.A. Calcium carbonate precipitation by marine bacteria. Geomicrobiology 1981, 2, 375-388.

15. Riding, R. Microbial carbonates: the geological record of calcified bacterial-algal mats and biofilms. Sedimentology 2000, 47, 179-214, DOI 10.1046/j.1365-3091.2000.00003.x.

16. Zhuang, D.; Yan, H.; Tuckerd, M.E.; Zhao, H.; Han, Z.; Zhao, Y.; Sun, B.; Li, D.; Pan, J.; Zhao, Y.; Meng, R.; Shan, G.; Zhang, X.; Tang, R. Calcite precipitation induced by Bacillus cereus MRR2 cultured at different $\mathrm{Ca}^{2+}$ concentrations: Further insights into biotic and abiotic calcite. Chemical Geology 2018, 500, 64-87, DOI 10.1016/J.chemgeo.2018.09.018.

17. Castanier, S.; Le Metayer-Levrel, G.; Perthuisot, J-P. Ca-carbonates precipitation and limestone genesis the microbiogeologist point of view. Sediment. Geol. 1999, 126, 9-23.

18. Hammes, F.; Verstraete W. Key roles of $\mathrm{pH}$ and calcium metabolism in microbial carbonate precipitation. Rev. Environ. Sci. Bio/Technol. 2002, 1, 3-7.

https://link.springer.com/content/pdf/10.1023\%2FA\%3A1015135629155.pdf.

19. Douglas, S.; Beveridge, T.J. Mineral formation by bacteria in natural microbial communities. FEMS Microbiol. Ecol. 1998, 26, 79-88,

DOI 10.1111/j.1574-6941.1998.tb00494.x.

20. Castanier, S.; Métayer-Levrel, G.L.; Perthuisot, J-P. Bacterial Roles in the Precipitation of Carbonate Minerals. In Microbial Sediments; Riding, R.E., Awramik, S.M., Eds.; Springer-Verlag: Heidelberg, Berlin, 2000; pp. 32-39, DOI 10.1007/978-3-662-04036-2_5.

21. Schultze-Lam, S.; Fortin, D.; Davis, B.S.; Beveridge, T.J. Mineralisation of bacterial surfaces. Chem. Geol. 1996, 132, 171-181, DOI 10.1016/S0009-2541(96)00053-8.

22. Rivadeneyra, M.A.; Delgado, G.; Ramos-Cormenzana, A.; Delgado, R. Biomineralization of carbonates by Halomonas eurihalina in solid and liquid media with different salinities: crystal formation sequence. Res. Microbiol. 1998, 149, 277-287.

23. Southam, G. Bacterial Surface-Mediated Mineral Formation. In Environmental Microbe-Metal Interactions; Lovley, D., Ed.; ASM Press: Washington, 2000; pp. 257-276.

24. Braissant, O.; Decho, A.W.; Dupraz, C.; Glunk, C.; Przekop, K.M.; Visscher, P.T. Exopolymeric substances of sulfate-reducing bacteria: interactions with calcium at alkaline $\mathrm{pH}$ and implication for formation of carbonate minerals. Geobiology 2007, 5, 401-411, DOI 10.1111/j.1472-4669.2007.00117.x.

25. Decho, A.W. Overview of biopolymer-induced mineralization: What goes on in biofilms? Ecol. Eng. 2009, 30,1-8, DOI 10.1016/j.ecoleng.2009.01.003.

26. Ercole, C.; Cacchio, P.; Botta, A.L.; Centi, V.; Lepidi, A. Bacterially induced mineralization of calcium carbonate: the role of exopolysaccharides and capsular polysaccharides. Microsc. Microanal. 2007, 13, 42-50.

27. Braissant, O.; Verrecchia, E.P.; Aragno, M. Is the contribution of bacteria to terrestrial carbon budget greatly underestimated?. Naturwissenschaften 2002, 89, 366-70.

28. Arp, G.; Volker, T.; Reimer, A.; Michaelis, W.; Reitner, J. Biofilm exopolymers control microbialite formation at thermal springs discharging into the alkaline Pyramid Lake, Nevada, USA . Sediment. Geol. 1999, 126, 159-176.

29. McConnaughey, T.A.; Whelan, J.F. Calcification generates protons for nutrient and bicarbonate uptake. Earth Sci. Rev. 1997, 42, 95-117, DOI 10.1016/S0012-8252(96)00036-0.

30. Seifan, M.; Samani, A.K.; Berenjian A. Induced calcium carbonate precipitation using Bacillus species. Appl. Microbiol. Biotechnol. 2016, 100, 9895-9906, DOI 10.1007/s00253-016-7701-7.

31. Wright, D.T. The role of sulphate-reducing bacteria and cyanobacteria in dolomite formation in distal ephemeral lakes of Coorong region, South Australia. Sed. Geol. 1999, 126, 147-157.

32. Arp, G.; Reimer, A.; Reitner, J. Photosynthesis-induced biofilm calcification and calcium concentrations in Phanerozoic oceans. Science 2001, 292, 1701-1704.

33. Dittrich, M.; Obst, M. Are picoplankton responsible for calcite precipitation in lakes? Ambio 2004, 33, 559564, DOI 10.1579/0044-7447-33.8.559. 
34. Plée, K.; Pacton, M.; Ariztegui, D. Discriminating the role of photosynthetic and heterotrophic microbes triggering low-Mg calcite precipitation in freshwater biofilms (Lake Geneva, Switzerland). Geomicrobiol. J. 2010, 27, 391-399, DOI 10.1080/01490450903451526.

35. Power, I.M.; Wilson, S.A.; Small, D.P.; Dipple G.M.; Wan W.K.; Southam, G. Microbially mediated mineral carbonation: roles of phototrophy and heterotrophy. Environ. Sci. Technol. 2011, 45, 9061-9068, DOI 10.1021/es201648g.

36. Ehrlich, H.L. Geomicrobiology: its significance for geology. Earth-Sci. Rev. 1998, 45, 45-60.

37. Zhu, T.; Dittrich, M. Carbonate precipitation through microbial activities in natural environment, and their potential in biotechnology: a review. Front. Bioeng. Biotechnol. 2016, 4, 4.

38. Cardoso, R.; Pires, I.; Duarte, S.O.D.; Monteiro, G.A. Effects of clay's chemical interactions on biocementation. Applied Clay Sci 2018, 156, 96-103.

39. Morales, L.; Garzón, E.; Sánchez-Soto, SPJ; Romero E. Microbiological induced carbonate $\left(\mathrm{CaCO}_{3}\right)$ precipitation using clay phyllites to replace chemical stabilizers (cement or lime). Applied Clay Sci 2019, 174, $15-28$.

40. Anbu, P.; Kang, CH.; Shin, YJ.; So, JS. Formation of calcium carbonate minerals by bacteria and its multiple applications. SpringerPlus 2016, 5, 250. DOI 10.1186/s40064-016-1869-2.

41. Vekariya, M.S.; Pitroda, J. Concrete: New Era For Construction Industry. Intern. J. Eng. Tre. Tech. 2013, 4, 4128-4137.

42. Chahal, N.; Rajor, A.; Siddique, R. Calcium carbonate precipitation by different bacterial strains. Afr. J. Biotechnol. 2011, 10, 8359-8372.

43. Garland, J.L.; Mills, A.L. Classification and characterization of heterotrophic microbial communities on the basis of patterns of community-level sole-carbon-source utilization. Appl. Environ. Microbiol. 1991, 57, 23512359.

44. Dakora, F.D.; Phillips, D.A. Root exudates as mediators of mineral acquisition in low-nutrient environments. Plant and Soil 2002, 245, 35-47.

45. Abràmoff, M.D.; Magelhaes, P.J.; Ram, S.J. Image processing with ImageJ. Biophotonics Inter. 2004, 11, 3642.

46. Schneider, C.A.; Rasband, W.S.; Eliceiri, K.W. NIH Image to ImageJ: 25 years of image analysis. Nat. Methods 2012, 9, 671-675.

47. Garland, J.L. Analytical approaches to the characterization of samples of microbial communities using patterns of potential C source utilization. Soil Biol. Biochem. 1996, 28, 213-22.

48. Frąc, M.; Oszust, K.; Lipiec J. Community level physiological profiles (CLPP), characterization and microbial activity of soil amended with dairy sewage sludge. Sensors 2012, 12, 3253-3268.

49. Zak, J.C.; Willig, M.R.; Moorhead, D.L.; Wildman, H.G. Functional diversity of microbial communities: a quantitative approach. Soil Biol. Biochem. 1994, 26, 1101-1108.

50. Supraja, N.;Prasad T.N.V.K.V. Extracellular synthesis of Calcium Precipitating Bacteria Isolated from Rock Environment Region and its Characterization Studies. Advancements in Bioequivalence \& Bioavailability. 2018, 1 , issue 3.

51. Otlewska, A.; Gutarowska B. Environmental parameters conditioning microbially induced mineralization under the experimental model conditions. 2016, 63, 343351.

52. Marvasi, M.; Visscher, P.T.; Perito, B.; Mastromei, G.; Martinez, L .Physiological requirements for carbonate precipitation during biofilm development of Bacillus subtilis etfA mutant. FEMS Microbiol Ecol, 2010, 71, issue 3, 341-350.

53. Urzì, C.; Garcia-Valles M.; Vendrell M.; Pernice A. Biomineralization Process on Rock and Monument Surfaces Observed in Field and in Laboratory Conditions. Geomicrobiol. J. 1999, 16, 39-54.

54. Baskar, S.; Baskar, R.; Mauclaire, L.; McKenzie, J.A. Microbially induced calcite precipitation in culture experiments: Possible origin for stalactites in Sahastradhara caves, Dehradun, India. Curr. Sci., 2006, 90, No. 1, 58-64.

55. Smibert, R.M.; Krieg, N.R. General characterization. In Manual methods for general bacteriology; Gerhardt, P., Ed.; American Society for Microbiology: Washington, D.C. U.S.A., 1981; pp. 409-443.

56. Christensen, W.B. Urea Decomposition as a Means of Differentiating Proteus and Paracolon Cultures from Each Other and from Salmonella and Shigella Types. J. Bacteriol., 1946, 52 (4), 461-466. 
57. MacFaddin, J.F. Biochemical Tests for Identification of Medical Bacteria, 3rd; Williams \& Wilkins, Philadelphia, PA, 2000; p. 298; ISBN 0683053183.

58. NORMAL Commission. NORMAL 9/88 recommendations. Autotrophic and heterotrophic microflora: culture methods for isolation. CNR/ICR: Rome, 1990.

59. Martino, T.; Salamone, P.; Zagari, M.; Urzì, C. Adesione a substrati solidi e solubilizzazione del $\mathrm{CaCO}_{3}$ quale misura della capacità deteriorante di batteri isolati dal marmo Pentelico. Proceedings XI Meeting of the Italian Society of General Microbiology and Microbial Biotechnology (SIMGBM), Gubbio, Italy, 1992; pp. 249-250.

60. Andrei, A-S.; Păuşan, M.R.; Tămaş, T.; Har, N; Barbu-Tudoran, L.; Leopold, N.; Banciu, H.L. Diversity and Biomineralization Potential of the Epilithic Bacterial Communities Inhabiting the Oldest Public Stone Monument of Cluj-Napoca (Transylvania, Romania). Front Microbiol 2017, 8, 372, DOI 10.3389/fmicb.2017.00372.

61. Jones, D.L. Organic acids in the rhizosphere - a critical review. Plant Soil 1998, 205, 25-44.

62. Florenzano, G. Fondamenti di Microbiologia del Terreno; REDA: Rome, 1983; p. 123.

63. Marilley, J.; Aragno, M. Phylogenetic diversity of bacterial communities differing in degree of proximity of Lolium perenne and Trifolium repens roots. Appl. Soil Ecol. 1999, 13, 127-136.

64. Atlas, R.M.; Bartha, R. Microbial Ecology:Fundamentals and Applications, 4th ed.; The Benjamin/Cummings Publishing Co, Inc.: San Francisco, 1998; ISBN 0805306552.

65. Kourtev, P.S.; Ehrenfeld, J.G.; Haggblom, M. Exotic plant species alter the microbial community structure and function in the soil. Ecology 2002, 83, 3152-3166.

66. Ivanov, V.; Chu, J. Applications of microorganisms to geotechnical engineering for bioclogging and biocementation of soil in situ. Rev. Environ. Sci. Bio/Technol. 2008, 7, 139-153, DOI 10.1007/s11157-007-91263.

67. Burbank, M.B.; Weaver, T.J.; Williams, B.C.; Crawford, R.L. Urease activity of ureolytic bacteria isolated from six soils in which calcite was precipitated by indigenous bacteria. Geomicrobiol. J. 2012, 29, 389-395, DOI 10.1080/01490451.2011.575913.

68. Davis, M.J.; Gillaspie, A.G.; Vidaver, A.K.; Harris, R.W. Clavibacter: a new genus containing some phytopathogenic coryneform bacteria, including, Clavibacter xyli subsp. xyli sp. nov., subsp. nov. and Clavibacter xyli subsp. cynodontis subsp. nov., pathogens that cause ratoon stunting disease of sugarcane and bermudagrass stunting disease. Int. J. Bacteriol. 1984, 34, 107-1.

69. Riley, I.T. Serological relationships between strains of coryneform bacteria responsible for annual ryegrass toxicity and other plant pathogenic corynebacteria. Int. J. Syst. Bacteriol. 1987, 37, 153-159.

70. Riley, I.T.; Reardon, T. B.; McKay, A.C. Genetic Analysis of Plant Pathogenic Bacteria in the Genus Clavibacter Using Allozyme Electrophoresis. J. Gen. Microbiol. 1988, 134, 3025-3030.

71. Fernandez-Garayzabal, J.F.; Dominguez, L.; Pascual, C.; Jones, D.; Collins, M. Phenotypic and phylogenetic characterization of some unknown coryneform bacteria isolated from bovine blood and milk: description of Sanguibacter gen. nov. Lett. Appl. Microbiol. 1995, 20, 69-75.

72. Thompson, F. L.; Iida, T.; Swings, J. Biodiversity of Vibrios. J. Microbiol. Mol. Biol. Rev. 2004, 68, $403-431$.

73. Tubiash, H.S.; Chanley, P.E.; Leifson, E. Bacillary necrosis, a disease of larval and juvenile bivalve mollusks. I. Etiology and epizootiology. J. Bacteriol. 1965, 90, 1036-1044.

74. Okada, K.; Iida, T.; Kita-Tsukamoto, K.; Takeshi, H. Vibrios Commonly Possess Two Chromosomes. J. Bacteriol. 2005, 187, 752-757.

75. Rivadeneyra, M.A.; Delgado, R.; del Moral, A.; Ferrer, M.R.; Ramos-Cormenzana, A. Precipitation of calcium carbonate by Vibrio spp. from an inland saltern. FEMS Microbiol. Ecol. 1994, 13, 197-204.

76. Rodriguez-Navarro, C.; Jimenez-Lopez, C.; Rodriguez-Navarro, A.; Gonzalez-Muñoz, M.T. RodriguezGallego, M. Complex biomineralized vaterite structures encapsulating bacterial cells. Geochimica et Cosmochimica Acta. 2007, 71, 1197-1213. 